Canadian Journal of Fisheries and Aquatic Sciences

February 2009 ; Volume 66 (2) : Pages 291-311

http://dx.doi.org/10.1139/F08-193

(c) 2009 NRC Research Press Canada
Archimer http://www.ifremer.fr/docelec/ Archive Institutionnelle de ''Ifremer

The original publication is available at http://pubs.nrc-cnrc.gc.ca

\title{
The relative weight of traditions, economics, and catch plans in New Zealand fleet dynamics
}

\author{
Paul Marchal ${ }^{1,2,{ }^{*}}$, Philippe Lallemand ${ }^{1}$, and Kevin Stokes ${ }^{1}$ \\ ${ }^{1}$ Seafood Industry Council Ltd., 74 Cambridge Terrace, Wellington, New Zealand. \\ ${ }^{2}$ IFREMER, 150 Quai Gambetta, BP 699, 62321 Boulogne s/mer, France \\ *: Corresponding author : Paul Marchal, email address : Paul.Marchal@ifremer.fr
}

\begin{abstract}
We investigate the relative weights of catch plans, expected profit, and traditions in fishers' decision-making for five New Zealand fleets subject to an individual transferable quota (ITQ) management regime. Métiers were defined for these fleets as a combination of gears, management units, and a targeting index (either target species or statistical area). A nested logit random utility model was used to model the métier allocation of fishing effort in relation to catch plans, expected profit, and past fishing allocations. This study showed that traditions and catch plans appeared to be important determinants of fishers' behavior for these New Zealand fleets. The model developed in this study fitted the data generally well and was also able to predict, in most cases, future effort allocation both one month and one year ahead.
\end{abstract}

Résumé: Nous étudions le poids relatif des portefeuilles de captures, du profit attendu et des traditions dans le processus de prise de décision des pêcheurs, dans le cas de six flottilles néozélandaises gérées par des quotas individuels transférables (ITQ). Plusieurs métiers ont été définis pour ces flottilles, en utilisant une combinaison des engins de pêche, des unitès de gestion et d'un indice de ciblage (soit les espèces recherchées ou les régions statistiques). Un modèle de choix discrets imbriqué (« random utility model ») a été utilisé pour modéliser l'allocation de l'effort de pêche en métiers, en utilisant les plans de pêche, le profit attendu et les allocations de pêche passées comme variables explicatives. Nous montrons que les traditions et les plans de pêche sont d'importants déterminants du comportement de pêche dans le cas des flottilles néo-zélandaises étudiées. Le modèle développé dans cette étude est bien calibré par les données disponibles et peut permettre dans la plupart des cas de prévoir raisonnablement quelle sera l'allocation de l'effort de pêche un mois, et même un an à l'avance.

Keywords: Individual Transferable Quotas, Catch plans, fleet dynamics, New Zealand fisheries, Random Utility Model 


\section{Introduction}

Fleet dynamics, the key process bridging fisheries decision-makers and fish resources, has been subject to increased attention by the scientific community in the past 25 years (Hilborn 1985; Gillis 2003; Branch et al. 2006a). Research to date has mainly focused on the mechanisms of: (1) effort allocation (Gillis et al. 1993; Holland and Sutinen 1999; Poos and Rijnsdorp 2007), (2) entering/exiting fisheries (Bockstael and Opaluch 1984; Ikiara and Odink 1999; Pradhan and Leung 2004b), (3) technological changes (Kirkley et al. 2004; Rahikainen and Kuikka 2002; Marchal et al. 2007a), (4) discarding (Gillis et al. 1995; Pascoe and Revill 2004) and, (5) compliance (Nielsen and Mathiesen 2003).

In particular, the processes underlying the dynamics of effort allocation have in recent years been investigated through a number of research projects, conducted by fisheries biologists and/or economists (Reeves et al. 2008). This has to a large extent been driven by an increasing interest in the implementation of area-based fisheries management (Hutton et al. 2004; Murawski et al. 2005; Poos and Rijnsdorp 2007), but also in the context of fishers' reactions to pollution events such as an oil-spill (Collins et al. 2003).

Fishers' location choices may also be driven by available fishing opportunities, which reflect the relative quantity of each species (or stocks) they are entitled, or are incentivised, to catch. This is particularly true in management systems including ITQ (Individual Transferable Quota), which provide individual fishers or fishing companies with a share of the overall TAC (Total Allowable Catch) for each stock (Arnason 1993; Sanchirico et al. 2006).

In theory, ITQs create incentives for fishers to maximize the value of their catch and minimize harvest costs. They also create, in principle, economic incentives to avoid catch of species the fisher does not have quota for. In mixed-species ITQ fisheries, fishers have a portfolio of catch rights, the catch plan. They are expected to operate their fishing operations in such a way that their resulting catch mix matches their catch plan as much as possible. However, it is almost inevitable that fishers' species mix of catch will not exactly match their portfolio of catch rights (Annala et al. 1991; Branch et al. 2006b). First, even when fishers want to conform to their catch plan, they may at the same time want to achieve alternative objectives (e.g. maximizing profit, fishing according to traditions). Because these objectives may prove difficult to reconcile, their combination may lead to a mismatch between the fishers' catch mix and their species portfolio. Second, uncertainty (due to e.g. stock fluctuations or unforeseen weather conditions) is usually an ingredient of fishing operations, which may cause fishing outcomes, including catch composition, to differ substantially from initial expectations.

A number of bio-economic analyses have been carried out in relation to the impact of ITQ on biological sustainability, economic efficiency (Sigler and Lunsford 2001; Holland et al. 2005; Holland and Herrera 2006) and discarding practices (Branch 2006; Branch et al. 2006b). However, to our best knowledge, none of these studies have investigated the effects of individual catch rights on fishers' behavior. In the existing literature, fishers' behavior has been modeled in relation to maximizing expected profit or catch rates (Vignaux 1996; Dorn 2001; Salas et al. 2004), sometimes also in combination with traditions, and/or area closures (Holland 1999; Hutton et al. 2004; Poos and Rijnsdorp 2006). The approaches pursued to model fishers' behavior have included random utility models (Holland and Sutinen 1999; Hutton et al. 2004; Pradhan and Leung 2004a), random walks (Bertrand et al. 2005; Marchal et al. 2007b), dynamic programming (Babcock and Pikitch 1999), and the application of theoretical concepts such as ideal free distribution theory (Gillis et al. 1993; Rijnsdorp et al. 2000; Abernethy et al. 2007) and game theory (Trisak 2005).

The main objective of this study is to investigate the relative importance of catch plans, economics and traditions in fishers' decision-making for five New Zealand fleets regulated by ITQs. One of these fleets mainly targets hoki (Macruronus novaezelandiae), while the others mainly target snapper (Pagrus auratus). We describe the background of the case studies, characterise the five fleets being investigated and the different métiers (or fishing activities) they operate, and derive an estimate of fishers' catch plans based on available data. We then apply a RUM (Random Utility Model) to model and predict fishers' decision-making. A 
number of explanatory variables are investigated, and these are related to the fishers' catch portfolio, economics and traditions.

\section{Background}

\section{Management}

The main management framework of New Zealand fisheries is the Quota Management System (QMS), which has been implemented since 1986 (Batstone and Sharp 1999; Bess and Harte 2000; Hersoug 2002). For each stock managed under the QMS, a TAC is set at the beginning of the fishing year by the Minister of Fisheries, advised by the Ministry of Fisheries, mainly on the basis of ensuring stocks remain at or above a level capable of producing the maximum sustainable yield. For most of New Zealand stocks, including those harvested by the fisheries investigated here, the fishing year $n$ starts the $1^{\text {st }}$ October in year $n-1$ and finishes the $30^{\text {th }}$ September in year $n$. TACs are then allocated to, (1) customary (Maori) and recreational fishers, (2) a virtual compartment including mainly illegal fishing, and with the remainder allocated to (3) the commercial fishing sector. The shares of the TACs allocated to the commercial fishing sector are referred to as the Total Allowable Commercial Catches (TACC). TACCs are distributed to quota holders as ITQ shares. On the first day of the fishing year, each ITQ (expressed as a percentage of the TACC) generates for each quota holder, and each stock, a catching right (in kgs) referred to as the Annual Catch Entitlement (ACE), so that

$$
\mathrm{ACE}(\mathrm{kg})=\mathrm{TACC}(\mathrm{kg}) \times \mathrm{ITQ}(\%)
$$

ACE, like ITQ, is freely tradable on the open market. Despite that flexibility, and even where fishers are allowed to acquire catch rights after landing fish, aggregate commercial catches may not always match up with TACCs. Discarding is prohibited in New Zealand for almost all species managed under the QMS, but fishers are allowed to land species in excess of their $A C E$, even when the overall TACC for these species has already been exceeded. In that case, fishers are charged at the end of the fishing year a fee, or "deemed value", for each unit of catch they land above their ACE holdings at the time. The deemed value is set annually by the Minister of Fisheries, advised by the Ministry of Fisheries, at the same time as the TAC and the TACC. There is no clear policy or rationale as to how the deemed value is calculated. However, the level at which the deemed value is set may have dramatic consequences for the fisheries sustainability. While a high deemed value (i.e. well above the ACE price) may encourage fishers to shift target species when ACE is in short supply on the market, a deemed value set at a low level (i.e. close to or below the ACE price), may incite fishers to pay the charge requested and continue targeting the same stock, even when they have no ACE. For instance, the deemed value for hoki has been lower than the ACE price in 2007, and the TAC set for that stock was exceeded at the end of the fishing year.

\section{The case studies}

This study focuses on five fisheries case studies, one is a hoki fishery, and the other four are Northern snapper fisheries operated by different fleets.

The hoki fishery was initially developed by Japanese and Soviet vessels in the early 1970s on the hoki spawning areas off the west coast of the South Island, from mid-July to late August. The fishery has expanded since the late 1980s on separate spawning aggregations located in Cook Strait, the east coast of the South Island and at Puysegur Bank. Hoki catches are capped by one single TACC, which covers most of the New Zealand EEZ. In addition, following an informal agreement between the Minister of Fisheries and the industry, an allocation key is defined to split the TACC between the eastern and the western stock areas. In the mid-nineties, both the TACC and catches were around 250,000 t. Since 2000, 
successive reductions have led to a TACC of $100,000 \mathrm{t}$ in 2008 . The hoki fishery is mainly operated by large vessels with bottom trawls and, to a lesser extent, mid-water trawls. At the scale of a fishing operation (haul), the main commercial by-catch species are hake (Merluccius australis), ling (Genypterus blacodes) and silver warehou (Seriolella punctata). At the scale of a fishing trip, or of a fishing year, vessels involved in the hoki fishery may also target squids (Nototodarus gouldi, Nototodarus sloanii), barracouta (Thyrsites atun) and other species.

Snapper fisheries are among the most valuable coastal fisheries in New Zealand. The snapper stock harvested off the east coast of the North Island (hereby referred to as the Northern snapper) is the most important of the five snapper stocks in New Zealand waters (Figure 1). Since the inception of the QMS in 1986, the Northern snapper commercial catches have fluctuated between 4,000 and 6,000 t. The TACC has been set at 4,500 t since 1997. An important feature of the Northern snapper fishery is the relatively large quantity of recreational and customary catches. The Northern snapper fishery is mainly operated by small vessels $(<24 \mathrm{~m})$ fishing inshore with long-lines, bottom trawls and, to a lesser extent, Danish seines and fixed nets. The long-line fishery is mostly single-species, with snapper contributing to more than $90 \%$ of the total catches. The main commercial by-catch species of the bottom trawl, and Danish seine fisheries are, in various proportions: barracouta, flatfish, gurnard (Chelidonichtys kumu), John Dory (Zeus faber), kahawai (Arripis trutta), kingfish (Seriola lalandi), leatherjacket (Parika scaber), blue moki (Latridopsis ciliaris), tarakihi (Nemadactylus macropterus) and trevally (Pseudocaranx dentex). Of importance to the present investigation is the Bay of Plenty (Figure 1). Fishing in the Bay of Plenty is subject to specific management regulations including seasonal closures and limited use of trawling.

Fig.

\section{Material and methods}

\section{Fleets and métiers}

\section{Fleets}

Consistent with ICES (2003), a fleet was defined as a group of vessels of a certain size targeting a given group of species with a specific gear and, in the case of the Northern snapper fishery, fishing in management units $1 \mathrm{~A}$ and $1 \mathrm{~B}$ (Figure 1), in at least $50 \%$ of the days fished throughout a given year.

For the hoki middle-depth fishery, the fleet investigated (fleet 1) consisted of bottom-trawlers targeting hoki, hake, ling, silver warehou, squids and barracuta. Only vessels below $46 \mathrm{~m}$ were included in the analysis. The $46 \mathrm{~m}$ cutoff was chosen since trawlers above that size are not allowed to fish within the 12 nautical mile territorial sea boundary (i.e. inshore waters) (Table 1).

For Northern snapper fisheries, the main gears used were long-lines, bottom trawls and Danish seines and the main target species were either snapper, gurnard, John Dory, kahawai, tarakihi or trevally in the management units $1 \mathrm{~A}$ and $1 \mathrm{~B}$. Four fleets were then identified (Table 1): long-liners below $12 \mathrm{~m}$ (fleet 2), long-liners of length 12-24 m (fleet 3 ), bottom trawlers of length 12-24 m (fleet 4) and Danish seiners smaller than $24 \mathrm{~m}$ (fleet 5).

Métiers

Each fleet may operate different métiers, or fishing activities, throughout the year. Métiers may be characterized by a number of factors including target species, gears, statistical areas Table 1 around and management units. In our study, all decisions, and most particularly métier choices, were here modeled at the scale of a fishing trip. The different métier characteristics (target species, gears, statistical areas, management units) could in principle be altered within a trip. In such cases, we used the most commonly reported value for these factors during that trip. For instance, should a fisher target hoki and squid during respectively 80 and $20 \%$ of the days fished within one fishing trip, the target species associated to that trip would be hoki. In case 
of a tie, we selected the factor's value leading to the largest total catch. E.g. if during a trip a fisher dedicated exactly the same amount of time to target hoki and squid, and caught in total respectively $300 \mathrm{~kg}$ and $200 \mathrm{~kg}$ of fish when targeting these species, the target species associated to that particular trip would be hoki.

Two métier types have been tested in this study. Both métier types combine a gear, a management unit and a targeting index. The New Zealand QMS is based on 10 management units (1-10). In this study, we considered 11 management units, of which nine are consistent with the QMS (2-10), and two consist of a subdivision of management unit 1 into 1A (outside the Bay of Plenty) and $1 B$ (inside the Bay of Plenty) (Figure 1). The rationale for distinguishing management units $1 \mathrm{~A}$ and $1 \mathrm{~B}$ is that specific regulations apply in the Bay of Plenty. With métier type 1, the targeting index is the main target species as reported in the fishers' log-books, so an example of type 1 métier could be bottom trawling in management unit $1 \mathrm{~A}$ and targeting snapper. With métier type 2, the targeting index is the main statistical area visited by fishers during a fishing trip. Statistical areas are QMS-based, three-digit, subdivisions of the management units defined above. An example of type 2 métier could be midwater trawling in management unit 2 and in statistical area 015. To keep the number of métiers tractable and to limit the number of missing values, for both typologies, we aggregated the least frequent (used in less than $5 \%$ of the fishing trips) management units, gears and targeting indices into one single "Other" category. The métiers identified, using the two typologies, are shown in Table 1 for the five fleets under investigation. Figures 2 and 3 show the spatial distribution of fishing effort by fleet and by métier, using both typologies.

\section{Data}

\section{Catch and effort}

Relevant catch and effort data, collected in New Zealand log-books for the period 2001-2006, were provided by the Ministry of Fisheries for our study. Landing data were reported by fishing trip and statistical area. Fishing effort data were provided by gear, target species and fishing event. For example, one tow, or one set, and all its associated effort data constitutes a fishing event. The number of days at sea was used as a proxy for fishing effort for all fleets being investigated. More detailed and specific metrics could have been considered to characterize the fishing effort associated to particular gears (e.g. number of hours fished for trawlers, number of hooks soaked for long-liners). However, using such metrics would not allow comparing the fishing effort, or any variable derived from fishing effort, of métiers when these are using different gears. Using the number of days at sea allowed comparing fishing effort across the métiers operated by each fleet, even when different gears are used. The landing and effort table eventually used in the analysis was aggregated at the level of the fishing trip. Each fishing trip was linked to a quota holder, which could be the fisher, or a quota holding company, which contracts the fisher for that fishing trip.

\section{ACE holdings and trading prices}

For the purpose of this study, quarterly ACE holdings and trading prices were extracted from ACE and Quota Share registers for each stock and quota holder of interest over the period 2001-2006. The quarterly ACE holdings were calculated from the initial ACE holdings allocated at the start of the fishing year corrected by the net amount of ACE traded (i.e. purchases minus sales) during that quarter. ACE holdings and trading prices were linked to catch and effort by year, quarter and quota holder.

\section{Fish prices}

The only source of information available on fish prices is from a survey, which collects prices paid by licensed fish receivers to fishers. This survey has been conducted annually by the 
Ministry of Fisheries, and is used to calculate the levy charged to quota holders for the costs of fisheries management and scientific advice (e.g. stock assessments). Discussions with industry representatives suggested, however, that fish prices may include three elements of bias. First, it is uncertain whether the prices reported by licensed fish receivers include only the transaction prices or whether some costs associated with the fishing activity or the ACE rental have been deducted. Second, the surveyed prices are used to calculate a cost recovery levy and this may generate an incentive to report low prices. Third, because the survey is conducted annually, there are no estimates of seasonal prices. As no better information was available, we used the fish price data collected during the survey. The possible implications of using such data have been addressed in the Methods and in the Discussion.

\section{Deemed value}

Annual deemed values were available from the Ministry of Fisheries for all fish stocks under investigation. Some of these stocks are subject to a flat deemed value rate, i.e. a rate unchanged irrespective of the quantity of fish caught over the ACE. Other stocks, however, including hoki (since October 2003) and Northern snapper have a differential deemed value rate, which increases stepwise with the proportion of catches landed above the ACE.

\section{Relative expected catches}

In ITQ systems, fishers usually have catch plans. In New Zealand, catch plan information data are not available to the general public, and discussions with industry representatives were organized to collect such data. Most of the hoki and Northern snapper ACEs are held by quota holding companies. We planned to interview representatives of the companies who held the greatest proportion of ACEs for the two stocks. For both stocks, more than $50 \%$ of the TACC (4586 t) was held by only three companies in fishing year 2006. In total, we conducted interviews with representatives of four companies, which represented $30 \%$ and $20 \%$ of the ACE holdings of hoki and Northern snapper respectively. All the interviews were conducted between September 2007 and January 2008.

The discussions with the companies representatives suggested that catch plans were set before the start of the fishing year for each vessel or vessel size category and subject to adjustments throughout the fishing year. It was also suggested that the proportional contribution of each species in individual vessels' catch plans was fairly stable throughout the period investigated here. Two out of the four interviewed companies representatives also provided quantitative information, which could be used as a basis to estimate catch plans for the hoki and the snapper fisheries. This information was given in different formats, depending on the fleet being considered. For the hoki fleet, annual expected catches were supplied by vessel and fish stock (in tonnes), for 3 vessels (out of 28) from fishing year 2005 onwards. For the Northern snapper fleets, monthly expected catches by vessel and fish stock (in tonnes), were supplied for 8 vessels (out of 120) and for fishing year 2007.

In order to make use of this information, we derived the relative expected catch as the proportional contribution of each species' expected catch to the total expected catch for all species. We then extrapolated the relative expected catch to all fishing vessels and fishing years. In doing this extrapolation, we made two assumptions. First, we assumed that fishing vessels for which information was provided were representative of, and therefore could be extrapolated to, the fleet to which they belonged. Second, consistent with discussions held with industry representatives, we assumed that expected catches were changed little over the period of investigation. Therefore, for fleet 1, we extrapolated the 2005 relative expected catches to fishing years 2002-2004. For fleets 2-5, we extrapolated the 2007 relative expected catches to all earlier fishing years. 


\section{Methods}

\section{Model structure}

RUMs, i.e. Random Utility Models (McFadden 1974; Bockstael and Opaluch 1984; Holland and Sutinen 1999), have been used to model individual vessel choices. For each fleet, each individual vessel's skipper, $v$, may choose at the beginning of each fishing trip, $i$, among different métiers (alternatives), $m$. Each alternative has a utility function associated with it, which may here be interpreted as the expected benefit (in a broad sense) each individual derives from that alternative relative to other possible alternatives. The random utility function can be decomposed into deterministic and stochastic components. Different distributions may be contemplated for the stochastic component, leading to different model types. We applied here a nested logit model, as it imposes a hierarchical structure, which conceptually could accommodate the organization of the fishers' decision-making process (Holland and Sutinen 1999). The details on the structure of the random utility model used in this investigation may be found in Appendix A. The methodology has been implemented using the MDC procedure of software package SAS (SAS 2003).

\section{Explanatory variables}

A range of explanatory variables have been included in the model specification. Some of them (economics, risk management, tradition) are "usual suspect" variables, which have traditionally been used in a range of fisher behavior studies (Holland and Sutinen 1999; Hutton et al. 2004; Pradhan and Leung 2004a). Others, however, are specifically dedicated to explore how available catch plans affect fishers' behavior in mixed fisheries. To our best knowledge, such variables have never been investigated in past behavioral studies. We specify below the different explanatory variables and the levels at which they were introduced in the model structure.

\section{Expected profit}

We assumed here that the skipper of each individual vessel $v$ on fishing trip $i$ would estimate the expected monetary profit of choosing a given métier based on the most recent profit information and the profit from the same month in the previous year. Recent profit information was averaged over all vessels in the same fleet and all fishing trips in the same métier, as defined by the previous month's VPUE (Value Per Unit Effort). The seasonal component of VPUE was assumed to be related to VPUE 12 months previously averaged over all vessels belonging to each fleet. The seasonal component was necessary because a number of processes underlying the dynamics of profit, such as stock availability, fish prices and ACE prices, are seasonal.

Because stock densities are subject to important spatial variations, we assumed that the VPUE in both the previous month and the previous year were mostly taken into account at the bottom decision level of the model structure.

We refer to the VPUE in the previous month and the VPUE in the previous year respectively as the short-term and the long-term VPUE, and these may be formulated as:

$$
V P U E \_1_{f, m}=V P U E_{t-1, f, m}=\frac{1}{N_{s} N_{f} N_{m}} \sum_{s \in N_{s}} \sum_{v \in N_{f}} \sum_{i \in N_{m}}\left[\frac{\left(\pi_{t-1, s}-\chi_{t-1, s}\right) Y_{t-1, s, v, i}}{E_{t-1, v, i}}\right]
$$




$$
V P U E \_12_{f, m}=\operatorname{VPUE}_{t-12, f, m}=\frac{1}{N_{s} N_{f} N_{m}} \sum_{s \in N_{s}} \sum_{v \in N_{f}} \sum_{i \in N_{m}}\left[\frac{\left(\pi_{t-12, s}-\chi_{t-12, s}\right)_{t-12, s, v, i}}{E_{t-12, v, i}}\right]
$$

where :

VPUE_1 is the short-term (or previous month) VPUE, VPUE_12 is the long-term (or previous year) VPUE,

$t$ is one month of the fishing period being investigation $s$ is a specific stock,

$f$ is a specific fleet,

$N_{S}$ is the number of stocks caught by vessel $v$ during fishing trip $i$,

$N_{f}$ is the number of vessels belonging to fleet $f$,

$N_{m}$ is the number of fishing trips belonging to métier $m$,

$Y_{t, s, v, i}$ is the yield $(\mathrm{kg})$ obtained by vessel $v$ during fishing trip $i$ operated in month $t$ for fish stock $S$,

$E_{t, v, i}$ is the fishing effort (expressed in number of fishing operations) exerted by vessel $v$ during fishing trip $i$ operated in month $t$,

$\pi_{t, s}$ is the fish price of stock $s$ in month $t$,

$\chi_{t, s}$ is the cost of renting an ACE, or paying the deemed value, for stock $s$ in month $t$,

As explained in the Data section, fish prices were only available by fishing year $(y) . \pi_{t, s}$ may then be formulated as:

$\pi_{t, s}=\pi_{y, s}$

ACE prices ( $\chi_{q, s}^{A C E}$ ) were only available on a quarterly $(q)$ basis. As explained in the Data section, it is uncertain whether the cost of renting ACE, or paying the deemed value, is already included in the fish price (in which case $\chi_{t, s}=0$ ), or not (in which case $\chi_{t, s}>0$ ). Both scenarios were tested. With the second scenario $\left(\chi_{t, s}>0\right)$, we also made the assumption than when ACE prices exceeded the annual deemed value $\left(\chi_{y, s}^{D V}\right)$, fishers would rather choose to pay the penalty than to rent an ACE. $\chi_{t, s}$ may then be formulated as:

$$
\chi_{t, s}=\left\{\begin{array}{l}
\chi_{q, s}^{A C E} \text { if } \chi_{q, s}^{A C E}<\chi_{y, s}^{D V} \\
\chi_{y, s}^{D V} \text { if } \chi_{q, s}^{A C E} \geq \chi_{y, s}^{D V}
\end{array}\right.
$$

\section{Risk management}

Fishers may have different attitudes towards risk. Some of them, probably the majority, are risk-averse. These fishers will endeavor to minimize the risk of not achieving their expected profit. To the contrary, risk-seekers will explore the métiers for which the track records of 
profit are most uncertain, with the hope of exceeding the expected profit. In this investigation, we assume that the CV of last month and last year VPUE (respectively referred to here as short-term and long-term variability) represent the fishers' risk perception of operating a given métier, and these are integrated in the model structure at the bottom decision level.

\section{Traditions}

Fishers may, or not, operate the métiers for which they have the greatest experience. This can be reflected by an adherence towards either the most recent métier they have experienced (short-term adherence) or the métier they have operated in the previous year and during the same season (long-term adherence). For each vessel $v$, we represent these adherences by the proportion of fishing effort allocated by that vessel to each métier, (i) during the month preceding its fishing trip (short-term adherence), (ii) one year before its fishing trip (long-term adherence). Traditions may a priori have an influence on the choice of gears, management units, but also on target species and statistical areas. We define the short-term adherence at the bottom decision level (targeting index choice) and the top decision level (gear and management unit choice), respectively as ADH1_1 and ADH2_1. Similarly, we define the long-term adherence at the bottom and the top decision levels, respectively as $A D H 1 \_12$ and $A D H 2 \_12$. The adherence variables may be formulated as:

$$
\begin{aligned}
& A D H 1_{-} 1_{v, m}=A D H 1_{t-1, v, m}=\frac{\sum_{i \in N_{m}}\left[E_{t-1, v, j}\right]}{\sum_{m \in C_{g, \mu}} \sum_{i \in N_{m}}\left[E_{t-1, v, j}\right]}
\end{aligned}
$$

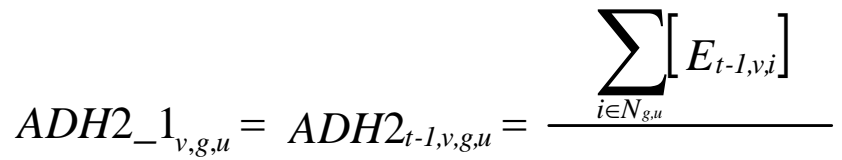

$$
\begin{aligned}
& \sum_{g, u \in C} \sum_{i \in N_{g, u}}\left[E_{t-1, v, i}\right] \\
& A D H 1_{-} 12_{v, m}=A D H 1_{t-12, v, m}=\frac{\sum_{i \in N_{m}}\left[E_{t-12, v, j}\right]}{T_{T}} \\
& \sum_{m \in C_{g, u}} \sum_{i \in N_{m}}\left[E_{t-12, v, i}\right] \\
& A D H 2 \_12_{v, g, u}=A D H 2_{t-12, v, g, u}=\frac{\sum_{i \in N_{g, u}}\left[E_{t-12, v, i}\right]}{{ }} \\
& \sum_{g, u \in C} \sum_{i \in N_{g, u}}\left[E_{t-12, v i}\right]
\end{aligned}
$$


where $C_{g, u}$ is the subset of métiers operated with gear $g$ and in management unit $u$ and $C$ is the set of possible combinations of gears and management units.

\section{Catch plans and penalty functions}

Maximizing expected profit does not necessarily guarantee the best economic return for fishers operating mixed-fisheries. This is particularly true for the New Zealand ITQ fisheries. For instance, in New Zealand, the quota owners may not necessarily be fishers. As a result, a number of fishers have contractual arrangements with quota holding companies. In return, fishers are contracted to land a pre-agreed species composition. Fulfilling the contract does not necessarily provide the best economic return fishers could expect from a fishing trip, but it gives them an access to ACE and a channel to sell their fish at an appropriate price. To the contrary, if fishers' catch composition is too different to that contracted, they may pay a high deemed value and may even not be in a position to sell fish they landed in excess, while they may not be in a position to honor their contract when landing an insufficient amount of other fish.

In this study, we developed penalty functions, which measure the difference, averaged over all stocks, between the catch plan owned by fishers before they start a fishing trip and the catch composition they expect from that trip when operating a given métier. A catch plan $\left(Z_{s}\right)$ is here defined for any stock $s \in N_{S}$ as the proportion of the catch weight planned for stock $s$, relative to the total catch weight planned for all stocks included in the catch plan.

Similar to the approach followed to estimate the expected profit, we assumed here that the skipper of each individual vessel $v$ operating fishing trip $i$ could in principle estimate the expected catch composition when choosing a given métier based on the 1- and 12-month lag yields averaged over, all vessels belonging to the same fleet and, all fishing trips belonging the same métier.

Catch plans are defined by stock, which themselves consist of a combination of species and management units. Catch plans could therefore determine the choice of gears and management units at the top decision level. Because stock densities are subject to important spatial variations, we assumed that yields in both the previous month and the previous year could influence métier choices at the bottom decision level. Overall, the penalty functions may then potentially influence métier choice at both top and bottom decision levels. We therefore define four penalty functions variables to represent the short-term consistency between catch plans and expected catch compositions at both bottom and top decision levels (respectively PEN1_1 and PEN2_1) and the long-term consistency for each of these levels (respectively PEN1_12 and PEN2_12). The penalty functions may be formulated as:

$$
\begin{aligned}
& P E N 1 \_1_{f, m}=P E N 1_{t-1, f, m}=\frac{1}{N_{S} N_{f} N_{m}} \sum_{s \in N_{s}} \sum_{v \in N_{f}} \sum_{i \in N_{m}}\left[\frac{Y_{t-1, s, v, i}}{\sum_{s \in N_{s}} Y_{t-1, s, v, j}}-Z_{t, s, v, j}\right]^{2} \\
& P E N 2 \_1_{f, g, u}=P E N 2_{t-1, f, g, u}=\frac{1}{N_{S} N_{f} N_{g, u}} \sum_{s \in N_{s}} \sum_{v \in N_{f}} \sum_{i \in N_{g, u}}\left[\frac{Y_{t-1, s, v, i}}{\sum_{s \in N_{s}} Y_{t-1, s, v, i}}-Z_{t, s, v, i}\right]^{2}
\end{aligned}
$$




$$
\begin{aligned}
& P E N 1 \_12_{f, m}=P E N 1_{t-12, f, m}=\frac{1}{N_{S} N_{f} N_{m}} \sum_{s \in N_{s}} \sum_{v \in N_{f}} \sum_{i \in N_{m}}\left[\frac{Y_{t-12, s, j, i}}{\sum_{s \in N_{S}} Y_{t-12, s, v, i}}-Z_{t, s, v, i}\right]^{2} \\
& P E N 2 \_12_{f, g, u}=P E N 22_{t-12, f, g, u}=\frac{1}{N_{S} N_{f} N_{g, u}} \sum_{s \in N_{s}} \sum_{v \in N_{f}} \sum_{i \in N_{g, u}}\left[\frac{Y_{t-12, s, v, i}}{\sum_{s \in N_{s}} Y_{t-12, s, v, i}}-Z_{t, s, v, i}\right]^{2}
\end{aligned}
$$

Low values of these penalty functions indicate a high degree of consistency between catch composition and catch plans and vice-versa. Because $Z$ is by construction common to the short-term and the long-term penalty functions, there is an element of redundancy between these variables. This was confirmed by preliminary runs of the RUM, which indicated a high correlation between the coefficients associated to short-term and the long-term penalty functions. We therefore retained in almost all subsequent analyses only the two short-term penalty functions. However, the long-term penalty functions were used in the 1-year ahead predictions, where short-term variables could not be included.

Discussions with representatives of some of the major quota holding companies in New Zealand suggested that catch plans are defined annually, before the start of the fishing year, and may be subject to intra-annual adjustments, during the fishing year. Based on these information, we have formulated the catch plans $(Z)$ as a $\varphi$-weighed linear combination of a strategic (or annual) catch plan (SCP) and of a tactical (or adjusted) catch plan (TCP):

$$
Z_{t, s, v, i}=(1-\varphi) S C P_{t, s, f}+\varphi T C P_{t, s, v, i}
$$

Both the strategic and the tactical catch plans are defined as a proportion of the catch planned for a certain stock relative to the total catch planned for all stocks included in the same catch plan. While the strategic catch plan is identical for all vessels belonging to fleet $f$, the tactical catch plan may vary from one vessel to another.

All companies interviewed indicated that strategic catch plans were subject to little interannual changes over the fishing years 2002-2006. In addition, some of the companies provided information, from which relative expected catches were extrapolated (see "Data" section). However, we did not have the elements to fully test how close the extrapolated relative expected catches were to the actual strategic catch plans. Two alternative approaches, building on different assumptions, have then been pursued to derive strategic catch plans.

First, we considered that the extrapolated relative expected catches could not be used as a reasonable proxy of the actual strategic catch plans. Based on the indication that strategic catch plans were subject to little inter-annual changes, we then assumed that the strategic catch plan of each fleet could be approached by the average catch composition achieved by that fleet in the previous year and in the same month. The strategic catch plans derived from 
this assumption are referred to as "A-type" strategic catch plans $\left(S C P_{-} A\right)$, and may be formulated as

$$
S C P_{-} A_{t, \mathrm{~s}, f}=\frac{Y_{t-12, \mathrm{~s}, f}}{\sum_{s \in N_{S}} Y_{t-12, \mathrm{~s}, f}}
$$

Second, we considered that the extrapolated relative expected catches could be used as a reasonable proxy of the actual strategic catch plans. W then derived a "B-type" strategic catch plan, building on these relative expected catches. As explained earlier, the relative expected catch (REC) data were available on a monthly basis for fleets 2-5, but not seasonally for fleet 1 . By contrast relative expected catches were available monthly, but in only one year (2007), for fleets 2-5. Two approaches have then been pursued; one for fleet 1 , and one for fleets 2-5.

For fleets $2-5$, the "B-type" strategic catch plan $\left(S C P \_B\right)$ was then simply derived as

$$
S C P \_B_{t, s, f}=R E C_{t, s, f}
$$

For fleet 1, we introduced a seasonal component in the strategic catch plan by combining relative expected catches with the seasonal distribution of each species catch in the previous year. If $y$ represents the fishing year, the "B-type" strategic catch plan was then formulated for fleet 1 as

$$
S C P_{-} B_{t, s, f}=R E C_{y, s, f}\left(\frac{Y_{t-12, s, f}}{\sum_{\tau \in y-1} Y_{\tau, s, f}}\right)
$$

In order to estimate the tactical catch plan, we made the assumption that the various intraannual adjustments operated on the strategic catch plan were directly linked to the current ACE availability. The tactical catch plan was then modeled as:

$$
T C P_{t, s, v, i}=\frac{\max \left[0, A C E_{q, s, v, i}-\sum_{\tau \leq t} Y_{\tau, s, v, i}\right]}{\sum_{s \in N_{s}}\left(\max \left[0, A C E_{q, s, v, i}-\sum_{\tau \leq t} Y_{\tau, s, v, i}\right]\right)}
$$

The parameter $\varphi$ balances the strategic and the tactical catch plans, and it is constructed to be in the range $[0,1]$. When $\varphi=0$, the strategic catch plan is never adjusted throughout the year. When $\varphi=1$, fishers do not follow any specific annual strategy, and the catch plan is entirely driven by ACE availability. Different values of $\varphi$ were tested in this investigation. First, we varied $\varphi$ between 0 and 1 (by step increments of 1/5) irrespective of when the fishing trip happened in the fishing year. Second, because ACE availability is generally more 
constraining at the end than at the start of a fishing year, we explored the possibilities of having catch plans driven entirely by (i) the strategic catch plan in the first quarter(s) of the fishing year $(\varphi=0)$, and (ii) the tactical catch plan in the last quarter(s) of the fishing year $(\varphi=1)$. Eighteen catch plan options have been investigated. Options A1-A9 build on "A-type" strategic catch plans, whereas options B1-B9 are derived from "B-type" strategic catch plans. The first six options within each strategic catch plan category (A1-A6 or B1-B6) assign values of $\varphi$ of $0.0,0.2,0.4,0.6,0.8$ and 1.0. Note that options $A 6$ and B6, which assume that fishers do not follow a specific annual strategy, are equivalent. Options A7 and B7 assume that the strategic catch plan is followed in the first three quarters of the fishing year and the tactical catch plan in the last quarter. Options A8 and B8 assume that the strategic catch plan is followed in the first two quarters of the fishing year and the tactical catch plan in the last two quarters. Finally, options A9 and B9 assume that the strategic catch plan is followed in the first quarter of the fishing year and the tactical catch plan in the last three quarters.

\section{Missing values}

In some occasions, the short-term and long-term VPUE, variability and penalty functions could not be derived for a number of métiers because no trips were operating these métiers over the period where these variables were calculated. Table 2 indicates that $6-33 \%$ of the observations included missing values. Removing these observations would be too costly. In order to fill in the missing observations, we made the assumption that the underlying reason for not operating a métier was that this métier was unattractive. Therefore, we replaced the missing values occurring in the explanatory variables by an unrealistically high value $(+1.0 \mathrm{E} 3$ in the case of the short-term and long-term variability and penalty functions) or an unrealistically low value (-1.0E3 in the case of the short-tern and long-term VPUE). We also evaluated the sensitivity of the results with respects to the choice of the imputed value by replacing the missing values with the maximum (variability and penalty functions) or the minimum (VPUE) observed for each fleet. This alternative replacement procedure aims at allowing the model to retain in principle some low probability of choosing the unattractive métiers.

\section{Model parameterization}

Table 2 around here

In order to parameterize the final run of the RUM, we carried out three preliminary analyses using the complete dataset (fishing years 2002-2006).

The first preliminary analysis was dedicated to the identification of the most appropriate catch plan. Different catch plan options were tested, using the short-term penalty functions as explanatory variables. For each catch plan, fleet and typology, we derived the proportion of correct métier predictions as the number of trips, for which the model correctly predicted the métier actually chosen, relative to the total number of trips in the dataset. The catch plan resulting in the largest proportion of correct métier predictions was then selected for future analyses.

The second preliminary analysis investigated the relative weight of the different explanatory variables in the model's goodness of fit, as reflected by McFadden's likelihood ratio index, which is analogous to the $\mathrm{R}^{2}$ in a classical linear regression model (McFadden 1974). Five runs were carried out, with different combinations of the explanatory variables. Run 1 includes short-term and long-term adherence to traditions at both decision levels. Run 2 includes only the penalty functions. Run 3 includes the VPUE and their CV at the top decision level and the short-term penalty at the bottom decision level. Run 4 is similar to run 3 , but also includes the short-term penalty at the top decision level. Run 5 included all the explanatory variables together, with the exception of the lag-12 month penalty functions which, as explained above, are to a large extent redundant with the lag-1 month penalty functions. Runs 3-5 were carried out separately with the two assumptions on fish prices (the 
cost of renting ACE, or paying the deemed value, is or is not already included in the fish price).

\section{Model predictions}

We evaluated the capacity of the parameterized model to predict future effort allocation by month and by métier based on a selection of explanatory variables. The model estimation was then based on the data covering only fishing years 2002-2005 (i.e. from $1^{\text {st }}$ October 2001 to 30 September 2005), and the predictions were made for the fishing year 2006 (i.e. from $1^{\text {st }}$ October 2005 to 30 September 2006). We investigated two types of predictions.

First, we evaluated the capacity of the model to make predictions one month ahead. The explanatory variables selected to that purpose were those of run 5, i.e. the short-term and long-term adherences, VPUE, variability and the short-term penalty functions.

Second, we evaluated the capacity of the model to make predictions one year ahead, and only the long-term adherences, VPUE, variability and penalty functions were selected.

\section{Results}

The results of the first preliminary analysis are shown in Table 3.

The proportion of correct predictions was dependent on the catch plan option. The proportion of correct predictions was always lower than $50 \%$, suggesting that other variables than the penalty functions have an influence on fishers' decision-making. These have been investigated in subsequent runs of the model.

Consider métier type 1 . In the case of fleets $3-5$, the most suitable catch plan (i.e. that leading to the greatest proportion of correct predictions) appeared to be entirely ( $\varphi=0.0)$ or mainly $(\varphi=0.2)$ driven by the strategic plan set at the start of the fishing season. In the case of fleet 2 , the most suitable catch plan appeared to be mainly $(\varphi=0.6)$ driven by ACE availability. In the case of fleet 1 , fishers appeared to base their catch plan on their initial strategic catch plan for the first three quarters of the fishing year, only to adjust it to prevailing ACE availability during the last quarter. Except for fleet 2, the most suitable catch plans were those calculated using the previous year's catch composition.

Consider métier type 2. For fleet 1, 4 and 5, the most suitable catch plan appeared to be entirely $(\varphi=0.0)$ or mainly $(\varphi=0.2)$ driven by the strategic plan. In the case of fleet 2 , fishers appeared to base their catch plan on their initial strategic catch plan for the first three quarters of the fishing year, only to adjust it to prevailing ACE availability during the last quarter. In the case of fleet 3 , the most suitable catch plan appeared to be mainly $(\varphi=0.6)$ driven by ACE availability. In the case of fleet 3 , effort allocation does not seem to be affected by catch plans, irrespective of the option retained. The most suitable catch plans were those calculated using the previous year's catch composition (fleets 1 and 5) or those extrapolated from actual data (fleets 2-4).

Tables 4 and 5 present the results of the second preliminary analysis carried out with the most appropriate catch plans (as identified in Table 3), and assuming that the cost of renting ACE, or paying the deemed value, had to be deducted from the available fish price. The alternative assumption (costs already including in fish price) was tested and never lead to an improvement of the model's goodness of fit, for any of the runs, and it was not considered any more in subsequent analyses.

The adherence (or tradition) variables contribute the most to the model's explained variability for all fleets and métier typologies (33-79\%) (Table 4). The penalty functions alone also explain a substantial amount of the model's variability (4-32\%). Combining the economic variables with the penalty functions did not result in a substantial increase in the McFadden's likelihood ratio index. With all variables included, the McFadden's likelihood ratio index was reasonably high, above $34 \%$ for all fleets and métier typologies, and above $50 \%$ for all fleets 
except 4 (Table 4). In a few cases (all with intermediary runs 3 and 4), the McFadden's likelihood ratio index statistic could not be computed, as a result of one of the inclusive values being constrained to zero. This result indicates that in these particular occasions, the decision-tree built to reflect fishers' decision-making, combined with the model formulation of runs 3 and 4 , did not provide useful fits to the data.

The outcomes of run 5 are shown in Table 5 . Almost all the coefficients associated to the adherence variables are highly significant $(p<0.0001)$ for all of the combinations of fleets and métier typologies. These results indicate that fishers' behavior is generally strongly influenced by the way they traditionally allocate their fishing effort, irrespective of the prevailing conditions.

For all combinations of fleets and métier typologies, at least one of the two coefficients associated to the short-term penalty functions was significant $(p<0.05$ and/or $p<0.0001)$ and took a negative value. In five out of ten combinations, both coefficients were significantly lower than zero. Significantly positive values for such coefficients occurred for three combinations, and were due to colinearity between the coefficients associated to the two short-term penalty functions. For all combinations of fleets and métier typologies, at least one of the two coefficients associated to the expected VPUE was significantly greater than zero, while at least one of the two coefficients associated to variability was significantly lower than zero. The inclusive values are in almost all cases in the range $[0,1]$, suggesting that the nested logit was a correct approach to structure the RUM. In only two cases, the inclusive values were greater than 1 (IV3=1.11 for fleet 2 and métier typology 1; IV3=1.35 for fleet 5 and métier typology 2).

We also operated the final run by replacing missing values by the maxima (variability and penalty functions) or minima (VPUEs) observed for each fleet. The outcomes were similar to the base case. In particular, the McFadden's likelihood ratio index never differed by more than $1 \%$ compared to the base case, for any combination of fleets and métier types.

Tables $6 a-b$ and Figures 4 and 5 visualize the performances of our model with respect to both the calibration to the data of fishing years 2002-2005 (i.e. from $1^{\text {st }}$ October 2001 to 30 September 2005) and the capacity to predict future effort allocation in fishing year 2006 (i.e. from $1^{\text {st }}$ October 2005 to 30 September 2006) using the past data. The calibration of the RUM to fishing years 2002-2006 data is reasonably good for the main métiers operated by the fleets under investigations. The percentage of correct métier allocation was above $50 \%$, for 23 out of the 30 combinations of fleets and métiers defined with typology 1, and for 29 out of 40 combinations of fleets and métiers defined with typology 2. Only the least represented métiers were not so well predicted. In most of the combinations of fleets and métier typologies, our model could predict reasonably well future effort allocations one month and even one year ahead, for all fleets except the snapper trawlers, and for the most important operated métiers (e.g. Figures $4 \mathrm{a}-\mathrm{c}, \mathrm{e}$ and $5 \mathrm{a}-\mathrm{c}$ ). There were cases however where good calibration and good predictions 1 month ahead did not necessarily result in good predictions 12-month ahead (e.g. Figure 5e). The fit was generally poor for the snapper trawlers, although the tendencies were roughly picked up for the main métiers (Figures $4 \mathrm{c}$ and $5 \mathrm{c}$ ).

\section{Discussion}

This study bears out that traditions are an important determinant of fishers' behavior. Holland and Sutinen (1999) demonstrated that the tradition variables were by far the most influential determinants of effort allocation for New England trawlers. Pradhan and Leung (2004a) showed that Hawaii's long-line fishers exhibited a strong adherence to previously operated métiers. However, it remains to be evaluated which factors are actually incorporated in the tradition variables, and which ones are the most influential on fishers' behavior. Traditions surely incorporate habits, but probably also the fishers' experience of how to fish on appropriate fish aggregations. When fishers have a catch plan, appropriate fish aggregations are not only characterized by a high density of fish, but also by the mix of species required that plan. Eventually, traditions incorporate the fishers' ability to fish in a profitable way, and 
may overlap to some extent with the other variables examined in this study (VPUE, catch plans). This probably why the tradition variables appeared as the most determinant factors of fishers' behavior for all the fleets investigated in this study.

A common assumption made is that fishers' behavior is determined by economics. The results of our investigations do not contradict this assumption. However, while a number of studies indicate that averaged past revenues are a determinant of métier choices (Holland and Sutinen 1999; Hutton et al. 2004), our analyses showed that the catch plans allocated to fishers are also influential in the case of the New Zealand fleets being investigated, irrespective of the métier typology used.

To our knowledge, catch plans have never been explicitly integrated as explanatory variables in previous models of fishers' behavior. The reason why catch plans are a determinant of fishers' behavior may be directly linked to the nature of the New Zealand QMS. In ITQ fisheries, ACEs are allocated to fishers, either in the form of contracts with quota holding companies, or simply because fishers are themselves quota holders. It is therefore conceivable that matching catch species composition with catch plans is a realistic economic objective for New Zealand fishers. However, and as confirmed with discussions with industry representatives, such an objective is not necessarily consistent with the classical multispecies profit maximization goal, at the scale of the fishing trip.

Catch plans were here constructed as an estimated combination of an annual strategy and of an intra-annual adjustment to prevailing ACE availability. Overall, the catch plans appeared to be determined to a large extent by the annual strategy, and subject to little adjustments throughout the fishing year, for most fleets and métier types (hoki trawlers, Northern snapper trawlers and seiners for all typologies, small Northern snapper long-liners with métier based on statistical areas, medium Northern snapper long-liners with métier based on target species). Interpreting the nature of catch plans should be done cautiously, as they were calculated subject to assumptions. However, there are plausible reasons why catch plans are mainly influenced by an annual strategy. First, it may be hypothesized that fishers are generally able to follow their strategic catch plan most of the year. When they cannot adhere to the annual plan in a given month, they do not systematically seek for an adjustment in the following months and may well exceed their available ACE. This could be explained by the fact that in New Zealand, the balance between catch and ACE is only evaluated at the end of the fishing year. Therefore, fishers could operate with an insufficient provision of (or even without) ACE during most of the fishing year, and then balance their catches, or possibly pay the deemed value, at the end of the fishing year. In the case of hoki bottom trawlers (with métiers defined based on target species) and of small snapper long-liners (with métiers defined based on statistical areas), the catch plan appeared to consist of following the annual strategy in the first three quarters of the fishing year, and then to balance catches with available ACE in the last quarter. We did not have tangible data to determine why the catch plans of Northern snapper small long-liners (with métiers defined based on target species) and medium long-liners (with métiers defined based on statistical areas) were more subject to intra-annual adjustments than for the other combinations of fleets and métier types.

Generally, and except for some of the least represented métiers, the model developed in this study fitted the data reasonably, and was also able to predict in most cases future effort allocation both one month and one year ahead. These results could be used to inform management. Typically, catch options recommended by scientists to managers are based on the predicted response of stock biomass to different exploitation rate regimes. A common assumption made is to estimate the catchability in the prediction year using the historical value derived from the stock assessment. If effort allocation changes in the prediction year (in response to e.g. substantial shifts in TACs), the assumption of constant catchability could be at fault. The effort allocation model developed in this study could then be used to predict the short-term métier allocation of fishing effort, and thereby to refine the derivation of catchability.

This study had a number of limitations.

First, some observations had missing values, when some métiers were not operated over the period where explanatory variables were calculated. There is no easy way to resolve this 
problem. We have first reduced the number of missing values by regrouping rare métiers into more generic categories. Applying this initial pre-filter decreased the number of missing observations to $6-33 \%$, depending on the fleet and métier typology used. To fill in the remaining gaps, we then assumed that métiers were not operated because they were unattractive, with respect to the different explanatory variables included in the model. While this assumption is probably not unreasonable, fishers may have other reasons than those reflected in the explanatory variables of our model, for not operating specific métiers. These reasons could include in particular great operating costs, recurrently bad weather conditions, adverse fishing grounds. However, such information was not available to our analysis.

Second, catch plans were calculated subject to a number of assumptions. Two alternative approaches have been considered, one being to extrapolate across vessels and time data collected from the industry, and the other consisting of assuming that catch plans were based on the actual catch compositions from the previous year. We did not have elements to test how close either estimates were to the actual catch plans. We could however verify that the catch plans, as estimated using both approaches, were an important determinant of fishers' behavior. With a better data coverage, catch plans could be derived more accurately, and their estimated impact on fishers' decision-making might even be greater than suggested in this investigation.

Third, we expressed three concerns with regards to the quality of the fish price information used to derive VPUE. We tested the effect of including or not the ACE rental in the original fish price, and concluded that it hardly affected the results of the analysis. However, we did not explicitly address the other two concerns, that fish prices were likely underestimated, and also that seasonal fluctuations in fish prices were not reflected in our annual dataset. With more realistic fish price data, VPUE could have been a better profit proxy, and might have proved a more influential determinant of fishers' behavior than with the current estimate.

Fourth, we did not have the information on whether quotas or vessels were owned by skippers. In fact, it could be important to know whether ACEs are held by individual skippers or a quota holding company, and also whether the skipper is the vessel owner. There is evidence that different types of ownership may result in different strategies and catch plans (Sharma and Leung 1999, Esmaeili 2006).

The succession of decisions made by fishers when electing a métier has here been represented as a two level process. First, fishers choose a gear and a broad management unit and second, they refine their choice based on either a target species or a statistical rectangle. This hierarchical structure is a simplification of fishers' decision process, which was needed to keep the number of métiers tractable for modeling purposes. A third hierarchical level could be contemplated to reflect the decisions fishers may take in the course of their fishing trip. For instance, fishers may seek specific fish aggregations using echo-sounders (hoki fishery) or vessel aggregations suggesting high fish densities (Gillis and Showell 2002). To the contrary, fishers may try to avoid competition in congested areas (Gillis and Peterman 2000; Rijnsdorp et al. 2000). Accounting for that third hierarchical level would require refining the time and spatial scale of our métiers, which could be achieved by grouping fishing operations (i.e. tows or sets) instead of fishing trips into groups (Branch et al. 2005).

A logical step forward from this study would be to talk to the skippers themselves, so to verify the outcomes of our model. This approach could also be pursued to investigate the assumptions that have been made during the modeling process. Other logical follow-ups to our analyses could be to couple our approach with a model of vessels entering/exiting fishing fleets (Pradhan and Leung 2004b), and also to integrate the fleet dynamics processes in a comprehensive bio-economic model. This model could be used to make a fuller evaluation of the ITQ system. The scenarios to be investigated could include changes in TACs, ACE allocation rules, and the process of deemed value setting rules. 


\section{Acknowledgements}

This work was funded through the TRANZEF project (Transposing New Zealand fisheries management experiences to EU fleets and fisheries: a bio-economic modeling approach) by the European Union (contract no: MOIF-CT-2006-21646). The New Zealand Seafood Industry Council also provided assistance and funding. These supports are gratefully acknowledged. We are also thankful to Tom McClurgh (Aotearoa Fisheries Ltd), Tuck Destounis (Moana Pacific Ltd), Doug Loder (Talleys Ltd) and Collin Williams (Sealord Ltd) for providing qualitative and/or quantitative information relevant to the derivation of catch plans. Finally, we are really indebted to the very thoughtful comments of two anonymous referees, which we hope contributed to enhance the clarity of the manuscript.

\section{References}

Abernethy, K.E., Allison, E.H., Molloy, P.P., and Côté, I.M. 2007. Why do fishers fish where they fish? Using the ideal free distribution to understand the behaviour of artisanal reef fishers. Can. J. Fish. Aquat. Sci. 64: 1595-1604.

Annala, J.H., Sullivan, K.J., and Hore, A.J. 1991. Management of multispecies fisheries in New Zealand by individual transferable quotas. ICES mar. Sci. Symp. 193: 321-329.

Arnason, R. 1993. The Icelandic individual transferable quota system: a descriptive account. Mar. Res. Econ. 8: 201-218.

Babcock, E.A., and Pikitich, E.K. 1999. A dynamic programming model of fishing strategy choice in a multispecies trawl fishery with trip limits. Can. J. Fish. Aquat. Sci. 57: 357-370.

Batstone, C.J., and Sharp, B.M.H. 1999. New Zealand's quota management system: the first ten years. Mar. Pol. 23: 177-190.

Bertrand, S., Burgos, J.M., Gerlotto, F., and Atiquipa, J. 2005. Lévy trajectories of Peruvian purse-seiners as an indicator of the spatial distribution of anchovy (Engraulis ringens). ICES J. Mar. Sci. 62: 477-482.

Bess, R., and Harte, M. 2000. The role of property rights in the development of New Zealand's seafood industry. Mar. Pol. 24: 331-339.

Bockstael, N.E., and Opaluch, J.J. 1984. Behavioral modeling and fisheries management. Mar. Res. Econ. 1: 105-115.

Branch, T.A., Hilborn, R., and Bogazzi, E. 2005. Escaping the tyranny of the grid: a more realistic way of defining fishing opportunities. Can. J. Fish. Aquat. Sci. 62: 631-642.

Branch, T.A. 2006. Discards and revenues in multispecies groundfish trawl fisheries managed by trip limits on the U.S. West Coast and by ITQs in British Columbia. Bull. Mar. Sci. 78: 669-690.

Branch, T.A., Hilborn, R., Haynie, A.C., Fay, G., Flynn, L., Griffiths, J., Marshall, K.N., Randall, J.K., Scheuerell, M., Ward, E.J., and Young, M. 2006a. Fleet dynamics and fishermen behavior: lessons for fisheries managers. Can. J. Fish. Aquat. Sci. 63: 1647-1668.

Branch, T.A., Rutherford, K., and Hilborn, R. 2006b. Replacing trip limits with individual transferable quotas: implications for discarding. Mar. Pol. 30: 281-292.

Collins, A., Pascoe, S., and Whitmarsh, D. 2003. Pollution externalities and and fisheries: insights from a spatially-explicit bioeconomic model. Mar. Res. Econ. 18: 313-328.

Dorn, M.W. 2001. Fishing behavior of factory trawlers: a hierarchichal model of information processing and decision-making. ICES J. Mar. Sci. 58: 238-252.

Esmaeili, A. 2006. Technical efficiency analysis for the Iranian fishery in the Persian Gulf. ICES J. Mar. Sci. 63: 1759-1764.

Gillis, D.M. 2003. Ideal free distributions in fleet dynamics: a behavioral perspective on vessel movement in fisheries analysis. Can. J. Zool. 81: 177-187.

Gillis, D.M., and Peterman, R.M. 2000. The implications of interference and the ideal free distribution to the interpretation of CPUE. Can. J. Fish. Aquat. Sci. 55: 37-46. 
Gillis, D.M., Peterman, R.M., and Pikitch, E.K. 1995. Implications of trip regulations for highgrading: a model of the behavior of fishermen. Can. J. Fish. Aquat. Sci. 52: 402-415.

Gillis, D.M., Peterman, R.M., and Tyler, A.V. 1993. Movement dynamics in a fishery: application of the ideal free distribution to spatial allocation of effort. Can. J. Fish. Aquat. Sci. 50: 323-333.

Gillis, D.M., and Showell, M.A. 2002. Risk and information use in two competing fleets: Russian and Cuban exploitation of silver hake (Merluccius bilinearis). Can. J. Fish. Aquat. Sci. 59: 1275-1286.

Hersoug, B. 2002. New Zealand experience with right-based fisheries management Unfinished business. Eburon (Netherlands) Delft, Netherlands, 246 p.

Hilborn, R. 1985. Fleet dynamics and individual variation: why some people catch more than others. Can. J. Fish. Aquat. Sci. 42: 2-13.

Holland, D.S. 1999. A bioeconomic model of marine sanctuaries on Georges Bank. Can. J. Fish. Aquat. Sci. 57: 1307-1319.

Holland, D.S., and Herrera, G.E. 2006. Flexible catch-balancing policies for multispecies individual fishery quotas. Can. J. Fish. Aquat. Sci. 63: 1669-1685.

Holland, D.S., and Sutinen, J.G. 1999. An empirical model of fleet dynamics in New England trawl fisheries. Can. J. Fish. Aquat. Sci. 56: 253-264.

Holland, D.S., Bentley, N., and Lallemand, P. 2005. A bioeconomic analysis of management strategies for rebuilding and maintenance of the NSS rock lobster (Jasus edwardsii) stock in southern New Zealand. Can. J. Fish. Aquat. Sci. 62: 1553-1569.

Hutton, T., Mardle, S., Pascoe, S., and Clark, R.A. 2004. Modeling fishing location choice within mixed fisheries: English North Sea beam trawlers in 2000 and 2001. ICES J. Mar. Sci. 61: 1443-1452.

ICES 2003. Report of the Study Group for the development of fishery-based forecasts. ICES Document CM 2003, ACFM:08 Ref. D., 37 pp.

Ikiara, M.M., and Odink, J.G. 1999. Fishermen resistance to exit fisheries. Mar. Res. Econ. 14: 199-213.

Kirkley, J., Morrison Paul, C.J., Cunningham, S., and Catanzano, J. 2004. Embodied and disembodied technical change in fisheries: an analysis of the Sète trawl fishery, 1985-1999. Env. Res. Econ. 29: 191-217.

Marchal, P., Andersen, B., Caillart, B., Eigaard, O., Guyader, O., Hovgaard, H., Iriondo, A., Le Fur, F., Sacchi, J., and Santurtún, M. 2007a. Impact of technological creep on fishing effort and fishing mortality, for a selection of European fleets. ICES J. Mar. Sci. 64: 192-209.

Marchal, P., Poos, J.-J., Quirijns, F. 2007b. Linkage between fishers' foraging, market and fish stock density: examples from some North Sea fisheries. Fish. Res. 83: 33-43.

McFadden, D. 1974. Conditional logit analysis of qualitative choice behaviour, in Frontiers in econometrics, P. Zarembka [ed.], New York, Academic Press: 105-142.

Murawski, S.A., Wigley, S.E., Fogarty, M.J., Rago, P.J., Mountain, D.G. 2005. Effort distribution and catch patterns adjacent to temperate MPAs. ICES J. Mar. Sci. 62: 11501167.

Nielsen, J.R., and Mathiesen, C. 2003. Important factors influencing rule compliance in fisheries: lessons from Denmark. Mar. Pol. 27: 409-416.

Pascoe, S., and Revill, A. 2004. Costs and benefits of by-catch reduction devices in European brown shrimp trawl fisheries. Env. Res. Econ. 27: 43-64.

Poos, J.-J., and Rijnsdorp, A.D. 2007. An "experiment" on effort allocation of fishing vessels: the role of interference competition and area specialization. Can. J. Fish. Aquat. Sci. 64: 304313.

Pradhan, N.C., and Leung, P. 2004a. Modeling trip choice behavior of the longline fishers in Hawaii. Fish. Res. 68: 209-224.

Pradhan, N.C., and Leung, P. 2004b. Modeling entry, stay and exit decisions of the longline fishers in Hawaii. Mar. Pol. 28: 311-324.

Rahikainen, M., and Kuikka, S. 2002. Fleet dynamics of herring trawlers - change in gear size and implications for interpretation of catch per unit effort. Can. J. Fish. Aquat. Sci. 59: 531-541. 
Reeves, S.A., Marchal, P., Mardle, S., Pascoe, S., Prellezo, R., Thébaud, O., and Travers, M. 2008. From fish to fisheries: the changing focus of management advice. In Advances in fisheries science 50 years on from Beverton and Holt. $1^{\text {st }}$ ed. Edited by A. Payne, J. Cotter, and T. Potter. Blackwell Publishing 135-154.

Rijnsdorp, A.D., van Mourik Broekman, P.L., and Visser, E.G. 2000. Competitive interactions among beam trawlers exploiting local patches of flatfish in the North Sea. ICES J. Mar. Sci. 57: 894-902.

Salas, S., Sumaila, U.R., and Pitcher, T. 2004. Short-term decisions of small-scale fishers selecting alternative target species: a choice model. Can. J. Fish. Aquat. Sci. 61: 374-383.

Sanchirico, J.N., Holland, D., Quigley, K., and Fina, M. 2006. Catch-quota balancing in multispecies individual fishing quotas. Mar. Pol. 30: 767-785.

SAS 2003. SAS Institute Inc., Cary, NC, USA.

Sharma, K., and Leung, P. 1999. Technical efficiency of the longline fishery in Hawaii: an application of a stochastic production frontier. Mar. Res. Econ. 13: 259-274.

Sigler, M.F., and Lunsford, C.R. 2001. Effects of individual quotas on catching efficiency and spawning potential in the Alaska sablefish fishery. Can. J. Fish. Aquat. Sci. 58: 1300-1312.

Trisak, J. 2005. Applying game theory to analyze the influence of biological characteristics on fishers' cooperation in fisheries co-management. Fish. Res. 75: 164-174.

Vignaux, M. 1996. Analysis of vessel movements and strategies using commercial catch and effort data from the New Zealand hoki fishery. Can. J. Fish. Aquat. Sci. 53: 2126-2136.

\section{Appendix A. Details of the random utility model}

In a random utility model, the utility function $\left(U_{v, i, m}\right)$ associated to vessel $v$, fishing trip $i$ and métier $m$ can be decomposed into deterministic $\left(\boldsymbol{x}_{v, i, m}^{\prime} \alpha\right)$ and stochastic $\left(\varepsilon_{v, i, m}\right)$ components:

$U_{v, i, m}=x_{v, i, m}^{\prime} \alpha+\varepsilon_{v, i, m}$

where $\boldsymbol{x}_{v, i, m}^{\prime}$ is a vector of explanatory variables (to be detailed later) and $\boldsymbol{\alpha}$ is a vector of parameters to be estimated. Different distributions may be contemplated for the stochastic component $\varepsilon_{v, i, m}$, leading to different model types. The simplest forms are the conditional and the multinomial logit models (Hutton et al. 2004). However, a critical aspect of both distribution models is that they should accommodate the property of Independence of Irrelevant Alternatives. This property imposes in particular that the different alternatives in the choice set are independent, so a change in that choice set (e.g. by removing one alternative) should not affect parameters estimates. In many cases, this assumption appears to be violated (Wilen et al. 2002) and preliminary RUM runs carried out in this study with a conditional logit model also lead to the same conclusion. Alternative model types have been used in past studies to relax the Independence of Irrelevant Alternatives property in different ways, such as the mixed logit model (Pradhan and Leung 2004), and the nested logit model (Holland and Sutinen 1999).

Both the mixed logit and the nested logit forms could in principle be used here. We decided to apply the nested logit model, as it imposes a hierarchical structure, which conceptually could accommodate the organization of the fishers' decision-making process (Holland and Sutinen 1999).

We specify here a two-level nested logit model. We assume that fishers would select first (at the top decision level) one main gear and a management unit, and then choose (at the bottom decision level) a specific target species (métier type 1) or a more precise statistical area (métier type 2). Some explanatory variables belonging to vector $\mathbf{x}$ will come in the model at the top decision level (vector of variables $\mathbf{z}$ ), and others at the bottom decision level (vector of variables $\mathbf{y}$ ). 
With the two-level nested logit model, the unconditional probability $P(v, i, m)$ that vessel $v$ will choose a métier $m$ during fishing trip $i$ may be expressed as:

$P(v, i, m)=P(v, i, g, u) . P(v, i, m \mid g, u)$

$P(v, i, m \mid g, u)$ is the conditional probability that vessel $v$ will choose during fishing trip $i$ a métier $m$ after having selected gear $g$ and management unit $u . P(v, i, g, u)$ is the unconditional probability that vessel $v$ will choose during fishing trip $i$ a gear $g$ and a management unit $u$. $P(v, i, m \mid g, u)$ may be expressed as:

$$
P(v, i, m \mid g, u)=\frac{\exp \left\{\boldsymbol{y}_{v, i, m \mid g, u}^{\prime} \boldsymbol{\beta}\right\}}{\sum_{m \in C g, u} \exp \left\{\boldsymbol{y}_{v, i, m \mid g, u}^{\prime} \boldsymbol{\beta}\right\}}
$$

where $\beta$ is the vector of parameters to be estimated in relation to $\mathbf{y}$, and where $C_{g, u}$ is the subset of métiers operated with gear $g$ and in management unit $u$. $P(v, i, g, u)$ may be expressed as:

$$
P(v, i, g, u)=\frac{\exp \left\{\mathbf{z}_{v, i, g, u}^{\prime} \boldsymbol{\gamma}+I V_{g, u} \delta_{g, u}\right\}}{\sum_{g, u \in C} \exp \left\{\mathbf{z}_{v, i, g, u}^{\prime} \boldsymbol{\gamma}+I V_{g, u} \delta_{g, u}\right\}}
$$

$C$ is the set of possible combinations of gears and management units, $\gamma$ is the vector of parameters to be estimated in relation to $\mathbf{z}$, and the inclusive value $I V$ is the average utility that individuals may expect from each combination of gear and management unit. The inclusive value parameters $\delta$ are estimated by the RUM. Although these parameters should in principle be in the range $[0,1]$ if the nested logit is the correct model specification, Herriges and Kling (1996) demonstrated that values beyond that range could, under certain conditions, be locally consistent with such models. The inclusive values may be formulated as:

$$
I V_{g, u}=\ln \left\{\sum_{m \in C g, u} \exp \left\{\boldsymbol{y}_{v, i, m \mid g, u}^{\prime} \boldsymbol{\beta}\right\}\right\}
$$


The different parameters of the nested logit model are then estimated using the full information maximum likelihood method.

\section{References}

Herriges, J.A., and Kling, C.L. 1996. Testing the consistency of nested logit models with utility maximization. Econ. Lett. 50: 33-39.

Holland, D.S., and Sutinen, J.G. 1999. An empirical model of fleet dynamics in New England trawl fisheries. Can. J. Fish. Aquat. Sci. 56: 253-264.

Hutton, T., Mardle, S., Pascoe, S., and Clark, R.A. 2004. Modeling fishing location choice within mixed fisheries: English North Sea beam trawlers in 2000 and 2001. ICES J. Mar. Sci. 61: $1443-1452$.

Pradhan, N.C., and Leung, P. 2004. Modeling trip choice behavior of the longline fishers in Hawaii. Fish. Res. 68: 209-224.

Wilen, J.E., Smith, M.D., Lockwood, D., and Botsford, F.W. 2002. Avoiding surprises: incorporating fisherman behavior into management models. Bull. Mar. Sci. 70: 553-575. 


\section{Tables}

Table 1. Fleets and métiers investigated. Métiers are described in terms of main gears, management units and either target species (métier type 1) or statistical areas (métier type 2). $N_{f}$ is the total number of métiers for each fleet. $N_{m}$ is the total number of métiers for each fleet and each typology. The main target species are barracouta (Thyrsites atun), gurnard (Chelidonichtys kumu), John Dory (Zeus faber), hoki (Macruronus novaezelandiae), red cod (Pseudophycis bachus), snapper (Pagrus auratus), squids (Nototodarus sp.), tarakihi (Nemadactylus macropterus) and trevally (Pseudocaranx dentex).

\begin{tabular}{|c|c|c|c|c|c|c|c|c|c|}
\hline \multicolumn{4}{|l|}{ Fleets } & \multicolumn{6}{|l|}{ Métiers } \\
\hline Code & Description & & $N_{f}$ & Main gears & $\begin{array}{l}\text { Main } \\
\text { management units }\end{array}$ & Type & $N_{m}$ & Targeting index & Targeting index values \\
\hline \multirow[t]{2}{*}{1} & \multirow{2}{*}{\multicolumn{2}{|c|}{ hoki trawlers }} & 28 & $\begin{array}{l}\text { bottom \& mid- } \\
\text { water trawl }\end{array}$ & $2,3,7$ & 1 & 6 & $\begin{array}{lr}\text { Main } & \text { target } \\
\text { species }\end{array}$ & hoki, barracouta, red cod, squid \\
\hline & & & & & & 2 & 8 & $\begin{array}{l}\text { Main statistical } \\
\text { areas }\end{array}$ & $\begin{array}{l}\text { 015, 016, 017, 018, 020, 022, 023, } \\
024,034\end{array}$ \\
\hline \multirow[t]{2}{*}{2} & $\begin{array}{l}\text { snapper } \\
(<12 \mathrm{~m})\end{array}$ & long-liners & 28 & bottom long-line & $1 \mathrm{~A}, 1 \mathrm{~B}$ & 1 & 5 & $\begin{array}{l}\text { Main } \\
\text { species }\end{array}$ & snapper \\
\hline & & & & & & 2 & 9 & $\begin{array}{l}\text { Main statistical } \\
\text { areas }\end{array}$ & $002,003,005,006,007,008,009$ \\
\hline \multirow[t]{2}{*}{3} & $\begin{array}{l}\text { snapper } \\
(12-24 \mathrm{~m})\end{array}$ & long-liners & 28 & bottom long-line & $1 \mathrm{~A}, 1 \mathrm{~B}$ & 1 & 5 & $\begin{array}{l}\text { Main target } \\
\text { species }\end{array}$ & snapper \\
\hline & & & & & & 2 & 7 & $\begin{array}{l}\text { Main statistical } \\
\text { areas }\end{array}$ & $\begin{array}{l}002,003,005,006,007,008,009, \\
010\end{array}$ \\
\hline \multirow[t]{2}{*}{4} & $\begin{array}{l}\text { snapper } \\
\text { trawlers }\end{array}$ & bottom & 37 & bottom trawl & $1 \mathrm{~A}, 1 \mathrm{~B}$ & 1 & 10 & $\begin{array}{l}\text { Main target } \\
\text { species }\end{array}$ & $\begin{array}{l}\text { gurnard, John Dory, snapper, } \\
\text { tarakihi, trevally }\end{array}$ \\
\hline & & & & & & 2 & 8 & $\begin{array}{l}\text { Main statistical } \\
\text { areas }\end{array}$ & $003,005,008,009,010$ \\
\hline \multirow[t]{2}{*}{5} & $\begin{array}{l}\text { snapper } \\
\text { seiners }\end{array}$ & Danish & 27 & Danish seine & $1 \mathrm{~A}, 1 \mathrm{~B}$ & 1 & 7 & $\begin{array}{l}\text { Main } \\
\text { species }\end{array}$ & gurnard, John Dory, snapper \\
\hline & & & & & & 2 & 8 & $\begin{array}{l}\text { Main statistical } \\
\text { areas }\end{array}$ & $005,006,007,008,009,010$ \\
\hline
\end{tabular}


Table 2. Proportion of métiers for which the different short-term (lag-1 month) and long-term (lag-12 month) explanatory variables could not be calculated due to missing values.

\begin{tabular}{lllll}
\hline Metier & Fleet & \multirow{2}{*}{$\begin{array}{l}\text { No. } \\
\text { type }\end{array}$} & & \multicolumn{2}{l}{ Proportion of missing values in explanatory variables } \\
\cline { 4 - 5 } & 1 & 16602 & $25 \%$ & Long-term variables \\
\hline 1 & 2 & 63365 & $27 \%$ & $23 \%$ \\
& 3 & 20285 & $30 \%$ & $29 \%$ \\
& 4 & 36590 & $11 \%$ & $32 \%$ \\
& 5 & 19348 & $26 \%$ & $12 \%$ \\
2 & 1 & 22136 & $33 \%$ & $26 \%$ \\
& 2 & 114057 & $6 \%$ & $31 \%$ \\
& 3 & 28399 & $12 \%$ & $7 \%$ \\
& 4 & 29272 & $11 \%$ & $12 \%$ \\
& 5 & 22112 & $17 \%$ & $13 \%$ \\
\hline
\end{tabular}


Table 3. Results from the first preliminary analysis. Proportion of correct choice predictions obtained with the different penalty functions calculated with the assumption that the catch plan is a linear combination of the current relative ACE availability and of either (A-type strategic catch plan) previous year's catch proportion by stock, or (B-type strategic catch plan) a monthly catch proportion by stock estimated based on industry data. For each run, the only explanatory variable are the two short-term penalty functions. The highest proportion for each category is highlighted.

\begin{tabular}{|c|c|c|c|c|c|c|c|c|c|c|c|c|c|c|c|c|c|c|c|}
\hline \multirow[t]{3}{*}{ Métier type } & \multirow[t]{3}{*}{ Fleet } & \multicolumn{18}{|c|}{ Catch plan option } \\
\hline & & \multicolumn{9}{|c|}{ A-type strategic catch plan } & \multicolumn{9}{|c|}{ B-type strategic catch plan } \\
\hline & & A1 & A2 & A3 & A4 & A5 & A6 & A7 & A8 & A9 & B1 & B2 & B3 & B4 & B5 & B6 & B7 & B8 & B9 \\
\hline \multirow[t]{5}{*}{1} & 1 & 0.24 & 0.21 & 0.14 & 0.14 & 0.12 & 0.12 & 0.26 & 0.25 & 0.18 & 0.18 & 0.18 & 0.10 & 0.08 & 0.10 & 0.12 & 0.22 & 0.20 & 0.17 \\
\hline & 2 & 0.42 & 0.42 & 0.42 & 0.41 & 0.43 & 0.42 & 0.41 & 0.41 & 0.43 & 0.43 & 0.42 & 0.42 & 0.44 & 0.43 & 0.42 & 0.43 & 0.40 & 0.40 \\
\hline & 3 & 0.37 & 0.39 & 0.39 & 0.36 & 0.34 & 0.33 & 0.32 & 0.34 & 0.35 & 0.37 & 0.37 & 0.39 & 0.36 & 0.33 & 0.33 & 0.32 & 0.33 & 0.34 \\
\hline & 4 & 0.15 & 0.16 & 0.15 & 0.15 & 0.15 & 0.14 & 0.15 & 0.14 & 0.14 & 0.14 & 0.14 & 0.14 & 0.14 & 0.14 & 0.14 & 0.14 & 0.14 & 0.14 \\
\hline & 5 & 0.26 & 0.24 & 0.23 & 0.24 & 0.22 & 0.22 & 0.24 & 0.24 & 0.23 & 0.21 & 0.21 & 0.21 & 0.21 & 0.22 & 0.22 & 0.22 & 0.22 & 0.22 \\
\hline \multirow[t]{5}{*}{2} & 1 & 0.31 & 0.31 & 0.27 & 0.25 & 0.25 & 0.23 & 0.31 & 0.27 & 0.24 & 0.24 & 0.25 & 0.26 & 0.23 & 0.24 & 0.23 & 0.29 & 0.27 & 0.25 \\
\hline & 2 & 0.11 & 0.11 & 0.11 & 0.09 & 0.09 & 0.08 & 0.11 & 0.10 & 0.08 & 0.11 & 0.10 & 0.09 & 0.09 & 0.08 & 0.08 & 0.11 & 0.11 & 0.09 \\
\hline & 3 & 0.18 & 0.18 & 0.19 & 0.19 & 0.18 & 0.19 & 0.18 & 0.17 & 0.17 & 0.18 & 0.17 & 0.18 & 0.19 & 0.19 & 0.19 & 0.19 & 0.18 & 0.18 \\
\hline & 4 & 0.14 & 0.13 & 0.12 & 0.12 & 0.10 & 0.11 & 0.13 & 0.12 & 0.10 & 0.15 & 0.12 & 0.11 & 0.12 & 0.11 & 0.11 & 0.14 & 0.13 & 0.11 \\
\hline & 5 & 0.21 & 0.22 & 0.20 & 0.20 & 0.20 & 0.19 & 0.21 & 0.21 & 0.20 & 0.21 & 0.20 & 0.20 & 0.20 & 0.20 & 0.19 & 0.21 & 0.21 & 0.20 \\
\hline
\end{tabular}


Table 4. Second preliminary analysis. McFadden's likelihood ratio index statistic obtained with different parameterization of the RUM corresponding to runs 1-5. (*) indicates that the McFadden's likelihood ratio index statistic could not be computed. The cost of renting ACE, or paying the deemed value, has been deducted from the available fish price.

\begin{tabular}{|c|c|c|c|c|c|c|c|}
\hline \multirow[t]{2}{*}{ Fleet } & \multirow[t]{2}{*}{ Métier typology } & \multirow[t]{2}{*}{ Catch plan option } & \multicolumn{5}{|c|}{ Run no. } \\
\hline & & & 1 & 2 & 3 & 4 & 5 \\
\hline \multirow[t]{2}{*}{1} & 1 & A7 & 0.56 & 0.14 & * & * & 0.60 \\
\hline & 2 & $\mathrm{~A} 2$ & 0.48 & 0.21 & * & * & 0.53 \\
\hline \multirow[t]{2}{*}{2} & 1 & B4 & 0.79 & 0.32 & * & * & 0.81 \\
\hline & 2 & B7 & 0.74 & 0.04 & 0.05 & 0.05 & 0.74 \\
\hline \multirow[t]{2}{*}{3} & 1 & $\mathrm{~A} 2$ & 0.64 & 0.25 & * & * & 0.67 \\
\hline & 2 & B4 & 0.56 & 0.07 & 0.08 & 0.08 & 0.57 \\
\hline \multirow[t]{2}{*}{4} & 1 & $\mathrm{~A} 2$ & 0.33 & 0.04 & 0.06 & 0.06 & 0.34 \\
\hline & 2 & B1 & 0.38 & 0.05 & 0.06 & 0.07 & 0.40 \\
\hline \multirow[t]{2}{*}{5} & 1 & A1 & 0.62 & 0.14 & 0.17 & 0.17 & 0.64 \\
\hline & 2 & $\mathrm{~A} 2$ & 0.60 & 0.07 & 0.09 & 0.10 & 0.60 \\
\hline
\end{tabular}


Table 5. Detailed results of run 5. Parameters estimated by the nested logit RUM; $\left(^{*}\right) p<0.05,\left({ }^{*}\right) p<0.0001$. IV1-IV5 are the inclusive value parameters associated to the different level 2 métiers presented in Table 1. The explanatory variables shown are; ADH2_1 and ADH2_12: short-term and long-term adherences at the top level of the decision tree, ADH1_1 and ADH1_12: short-term and long-term adherences at the bottom level of the decision tree, PEN2 1: short-term penalty function at the top level of the decision tree, PEN1 1: short-term penalty function at the bottom level of the decision tree, VPUE_1 and VPUE_12: short-term and long-term VPUE at the bottom level of the decision tree, CV_1 and CV 12: short-term and long-term variability at the bottom level of the decision tree, IV1-IV5: inclusive values. LRI is the McFadden's likelihood ratio index. The cost of renting ACE, or paying the deemed value, has been deducted from the available fish price.

\begin{tabular}{|c|c|c|c|c|c|c|c|c|c|c|c|c|c|c|c|c|}
\hline \multirow[t]{2}{*}{ Fleet } & \multirow{2}{*}{$\begin{array}{l}\text { Catch } \\
\text { plan }\end{array}$} & \multirow{2}{*}{$\begin{array}{l}\text { Métier } \\
\text { typology }\end{array}$} & \multicolumn{14}{|c|}{ Explanatory variables and McFadden's LRI } \\
\hline & & & $\mathrm{ADH} 2 \_1$ & ADH2_12 & ADH1_1 & ADH1_12 & PEN2_1 & PEN1_1 & VPUE_1 & CV_1 & VPUE_12 & CV_12 & IV1 & IV2 & IV3 & IV4 \\
\hline \multirow[t]{2}{*}{1} & A7 & 1 & $0.0080^{*}$ & 0.0050 & $0.037 \overline{7 * *}$ & $0.0437^{\star \star}$ & $-0.0008^{*}$ & 0.0001 & $0.000 \overline{1}^{*}$ & -0.0001 & $0.0002^{*}$ & $0.0017^{\star *}$ & $0.38^{* *}$ & $0.33^{\star \star}$ & $0.22^{*}$ & $0.32^{\star *}$ \\
\hline & $\mathrm{A} 2$ & 2 & $0.0081^{\star *}$ & $0.0092^{\star *}$ & $0.0204^{* *}$ & $0.0170^{* *}$ & $\overline{-}^{-} .0007^{\star *}$ & $-0.0006^{\star}$ & $0.0001^{\star *}$ & -0.0002 & $0.0001^{\star *}$ & $-\overline{0.0006 * \star}$ & $0.75^{\star *}$ & $0.70^{* *}$ & $0.60^{\star *}$ & $0.70^{\star *}$ \\
\hline \multirow[t]{2}{*}{2} & B4 & 1 & $0.0096^{\star *}$ & $0.0092^{\star \star}$ & $0.0244^{\star *}$ & $0.0155^{\star \star}$ & $0.0014^{*}$ & $\overline{-}-0019^{\star \star}$ & 0.0000 & $\overline{0} .0011^{\star *}$ & 0.0000 & $\overline{0} .0006^{\star \star}$ & $0.61^{* *}$ & $0.57^{\star \star}$ & $1.11^{\star *}$ & - \\
\hline & B7 & 2 & $0.0153^{\star *}$ & $0.0136^{\star \star}$ & $0.0327^{\star *}$ & 0.0180 ** & -0.0005 & $-0.0007^{\star}$ & $0.0002^{*}$ & $-0.0007^{\star}$ & $0.0004^{\star *}$ & $-0.0005^{\star}$ & $0.37^{\star \star}$ & $0.33^{\star *}$ & $0.71^{\star \star}$ & 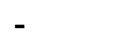 \\
\hline \multirow[t]{2}{*}{3} & $\mathrm{~A} 2$ & 1 & $0.0108^{* *}$ & $0.0106^{\star *}$ & $0.0236^{\star \star}$ & $0.0120^{* *}$ & $-0.0008^{*}$ & $-0.0007^{\star}$ & $0.0004^{*}$ & -0.0005 & -0.0002 & $-\overline{0.0013^{\star *}}$ & $0.46^{*}$ & $0.57^{* *}$ & 0.08 & - \\
\hline & B4 & 2 & 0.0033 & $0.0095^{\star}$ & $0.0301^{* *}$ & $0.0102^{\star *}$ & $-0.0006^{*}$ & $-0.0005^{\star}$ & -0.0000 & -0.0001 & -0.0003 & $\overline{0.0007^{* *}}$ & $0.75^{\star *}$ & 0.89 ** & $0.48^{\star *}$ & - \\
\hline 4 & $\begin{array}{l}\text { A2 } \\
\text { B1 }\end{array}$ & $\begin{array}{l}1 \\
2\end{array}$ & $\begin{array}{l}0.0120 * \star \\
0.0013\end{array}$ & $\begin{array}{l}0.0081^{\star \star} \\
0.0010\end{array}$ & $\begin{array}{l}0.0273^{\star *} \\
0.0272^{\star *}\end{array}$ & $\begin{array}{l}0.0121^{\star \star} \\
0.0148^{\star \star}\end{array}$ & $\begin{array}{l}-0.0004^{*} \\
0.0010^{\star}\end{array}$ & $\begin{array}{l}-0.0005^{\star} \\
- \\
0.0018^{\star \star}\end{array}$ & $\begin{array}{l}0.0000 \\
-0.0000\end{array}$ & $\begin{array}{l}-0.0004^{*} \\
0.0002\end{array}$ & $\begin{array}{l}0.0003^{\star *} \\
0.0001^{*}\end{array}$ & $\begin{array}{l}-0.0001 \\
-0.0003^{*}\end{array}$ & $\begin{array}{l}0.42^{\star \star} \\
0.88^{\star \star}\end{array}$ & $\begin{array}{l}0.35^{\star *} \\
0.89^{\star *}\end{array}$ & $\begin{array}{l}0.26^{\star} \\
0.79^{\star \star}\end{array}$ & - \\
\hline 5 & $\begin{array}{l}\text { A1 } \\
\text { A2 }\end{array}$ & $\begin{array}{l}1 \\
2\end{array}$ & $\begin{array}{l}0.0232^{\star *} \\
0.0146^{* *}\end{array}$ & $\begin{array}{l}0.0149 * * \\
0.0000\end{array}$ & $\begin{array}{l}0.0232^{\star *} \\
0.0239^{\star *}\end{array}$ & $\begin{array}{l}0.0100^{* *} \\
0.0162^{* *}\end{array}$ & $\begin{array}{l}0.0002 \\
-0.0004^{*}\end{array}$ & $\begin{array}{l}-0.0006^{*} \\
0.0004^{*}\end{array}$ & $\begin{array}{l}0.0002^{*} \\
0.0001^{*}\end{array}$ & $\begin{array}{l}-0.0001 \\
-0.0006^{*}\end{array}$ & $\begin{array}{l}0.0001 \\
0.0001^{* *}\end{array}$ & $\begin{array}{l}-0.0006^{*} \\
0.0000\end{array}$ & $\begin{array}{l}0.11 \\
0.72^{\star *}\end{array}$ & $\begin{array}{l}0.13 \\
0.90^{\star *}\end{array}$ & $\begin{array}{l}0.52^{\star} \\
1.35^{\star *}\end{array}$ & - \\
\hline
\end{tabular}


Table 6a. Proportion of correct métier choices $(p)$ as calibrated by the RUM using métier typology 1 , over fishing years 2002-2005 (i.e. from $1^{\text {st }}$ October 2001 to 30 September 2005), and predicted in the fishing year 2006 (with the 2002-2005 data used to calibrate the model). Predictions were made 1 month and 12 months ahead. $\mathrm{N}$ is the number of observations used to calculate $\mathrm{p}$.

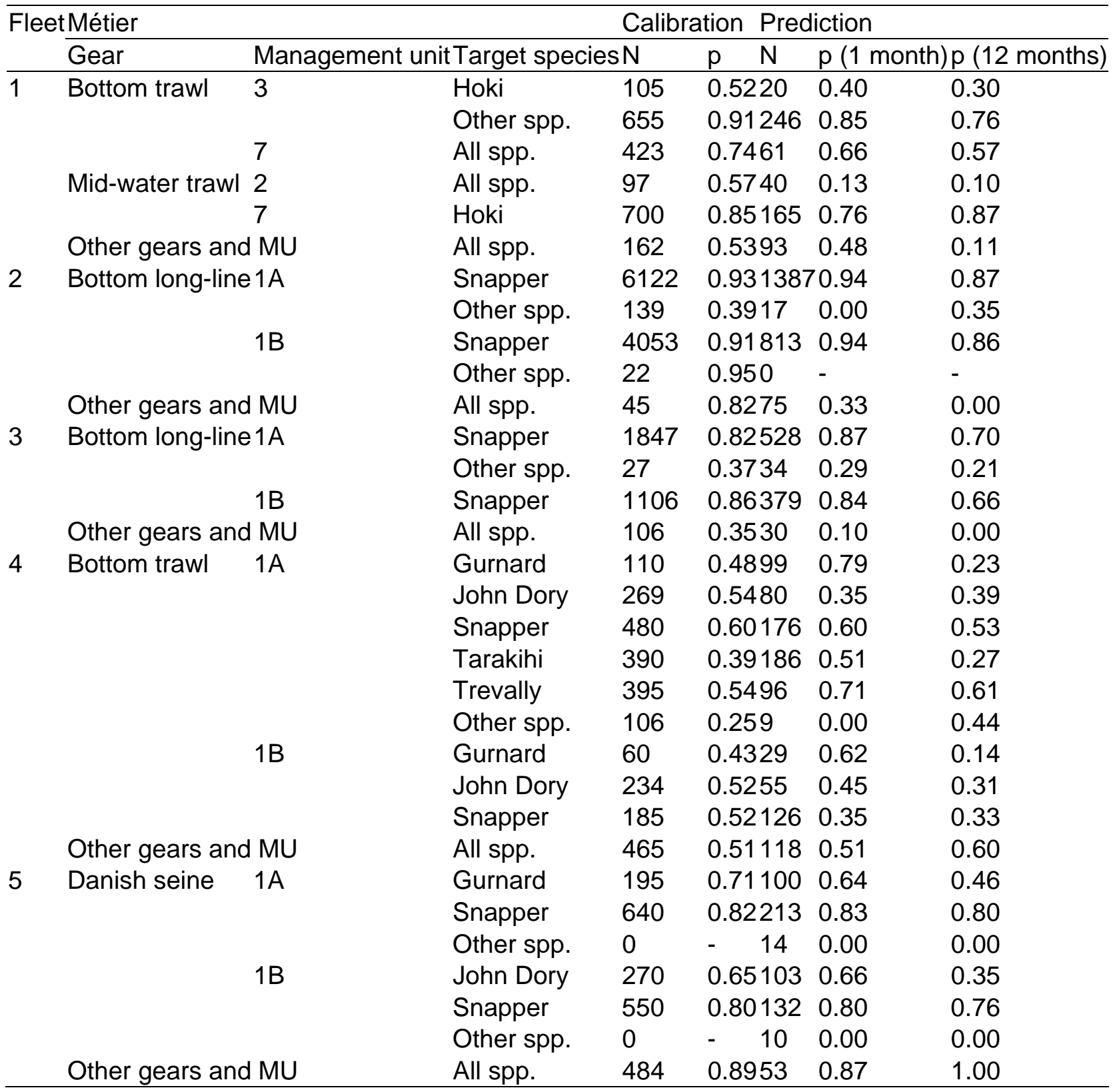


Table 6b. Proportion of correct métier choices $(p)$ as calibrated by the RUM using métier typology 2 , over fishing years 2002-2005 (i.e. from $1^{\text {st }}$ October 2001 to 30 September 2005), and predicted in the fishing year 2006 (with the 2002-2005 data used to calibrate the model). Predictions were made 1 month and 12 months ahead. $\mathrm{N}$ is the number of observations used to calculate $\mathrm{p}$.

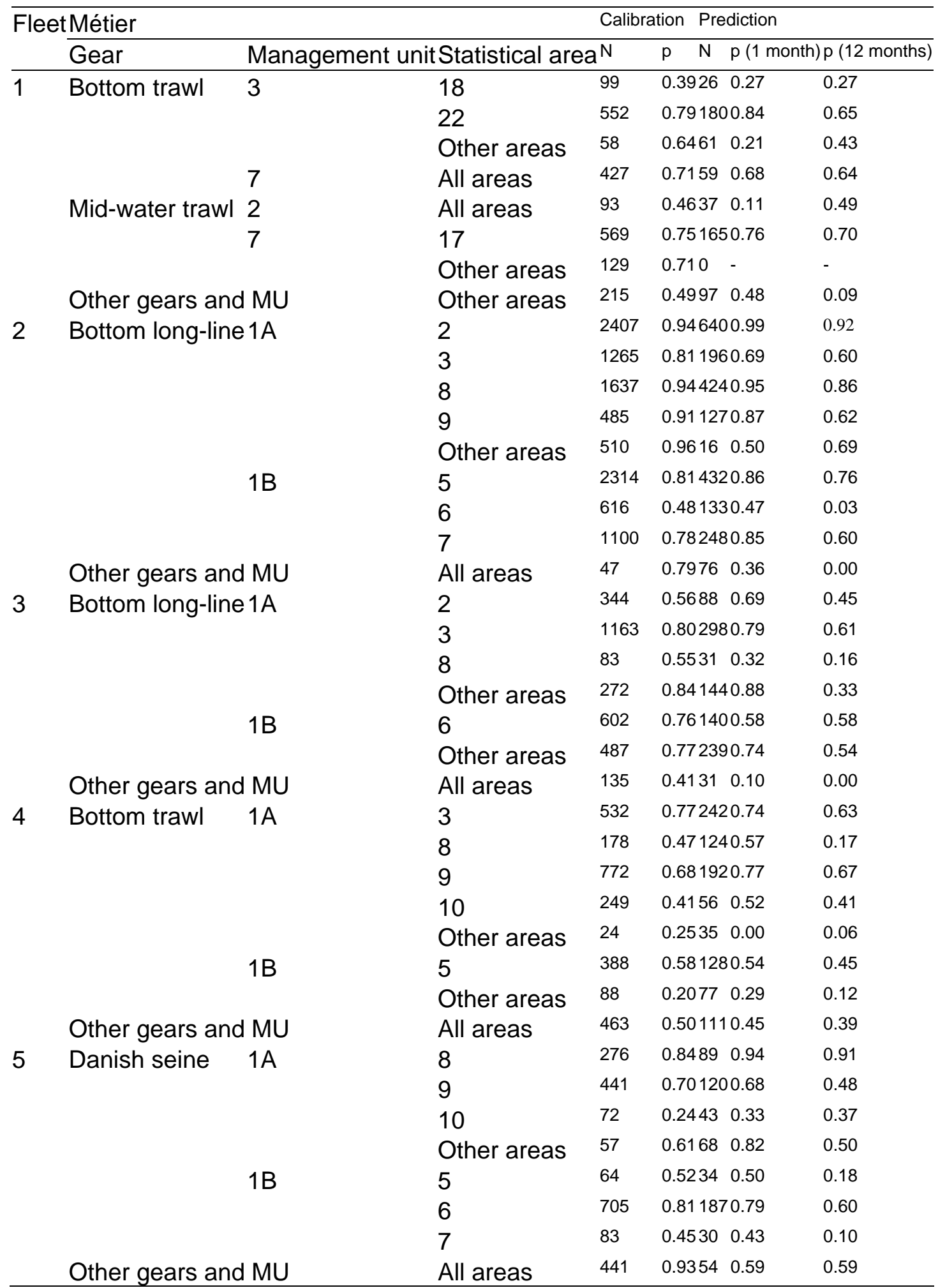


Figure 1. Marchal et al. [in color]

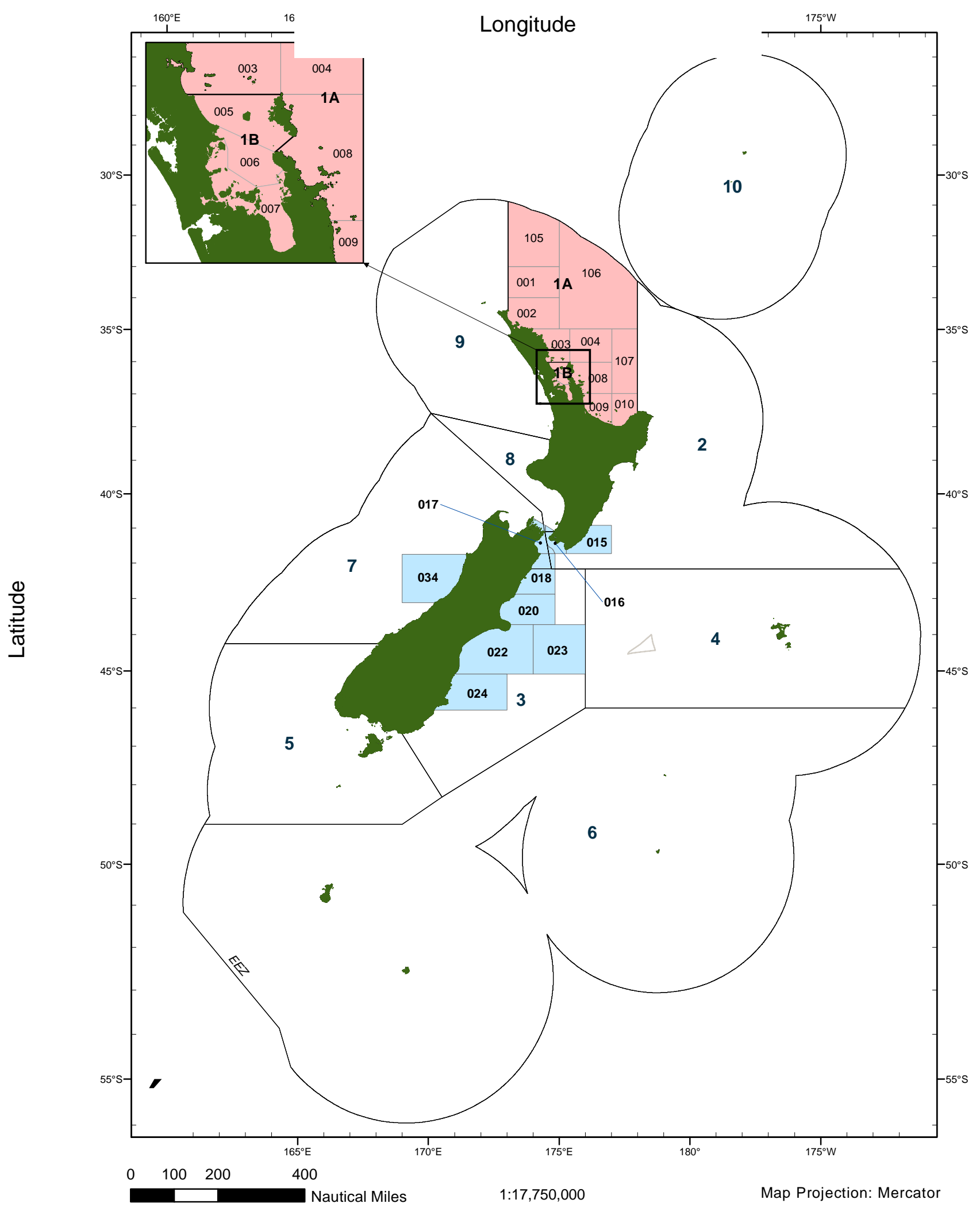


Figure 1. Map of New Zealand management units and of the main statistical areas relevant to the hoki fishery (fleet 1, in blue) and the Northern snapper fishery (fleets 2-5, in salmon). The insert expands the Bay of Plenty. The large-size, one- or two-digit, numbers refer to the management units, while the smallsize, three-digit, numbers refer to the statistical areas. 
Figure 2. Marchal et al. [in color]

\section{Longitude}

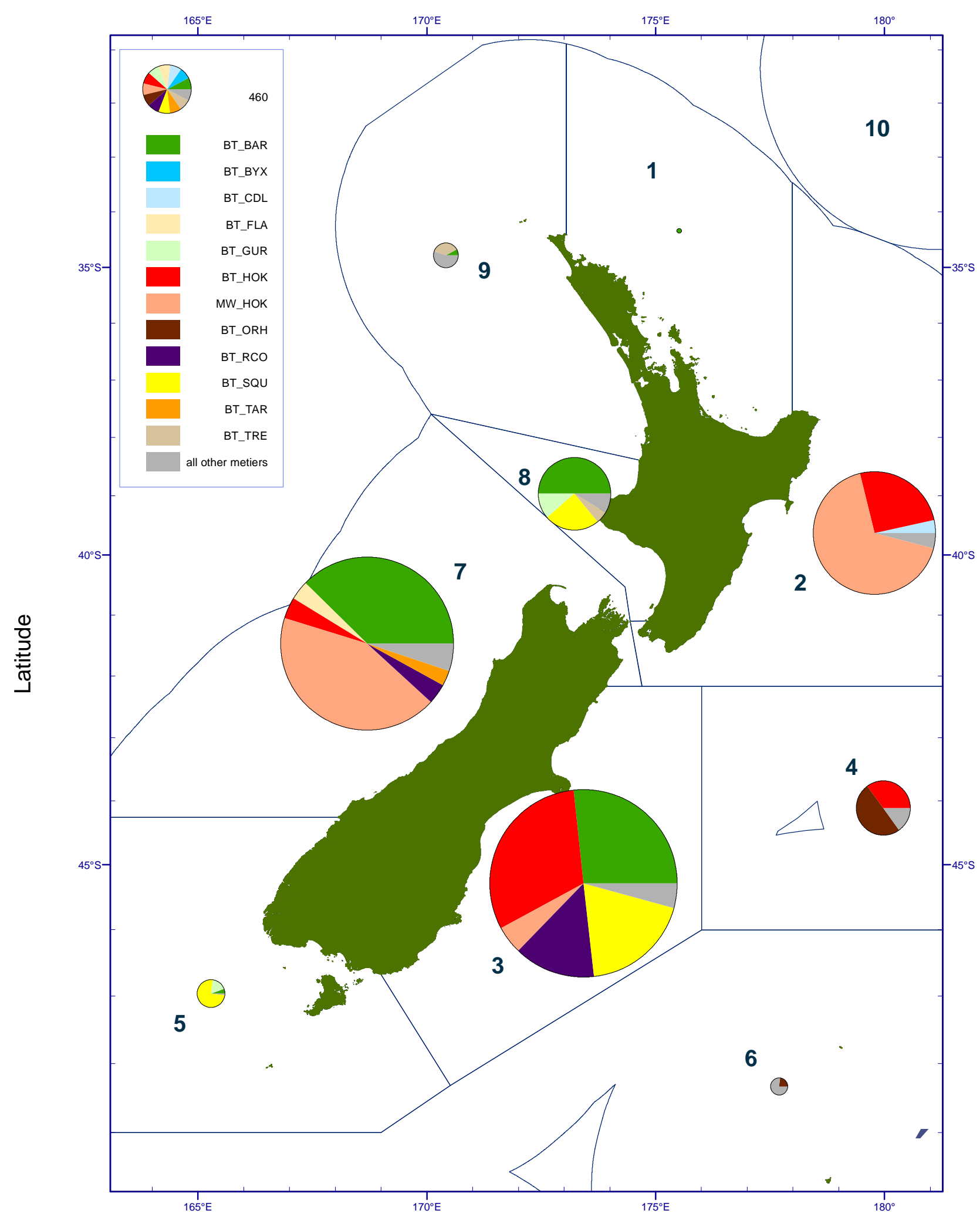


Figure 2. Spatial distribution of fishing effort for fleet 1 (hoki bottom trawlers) by métier using typology 1. The codes are; BT_BAR: bottom trawl barracouta (Thyrsites atun), BT_BYX: bottom trawl alfonsino (Beryx spp.), BT_CD̄L: bottom trawl black cardinal fish (Epigonus telescopus), BT_FLA: bottom trawl flatfish (various species), BT_GUR: bottom trawl gurnard (Chelidonichtys kumu), BT_HOK: bottom trawl hoki (Macruronus novaezelandiae), MW_HOK: mid-water trawl hoki, BT_ORH: bottom-trawl orange roughy (Hoplostethus atlanticus), BT_RCOO: bottom-trawl red cod (Pseudophycis bachus), BT_SQU: bottom-trawl squid (Nototodarus spp.), BT_TAR: bottom-trawl tarakihi (Nemadactylus macropterus), BT_TRE: bottom-trawl trevally (Pseudocaranx dentex). 
Figure 3. Marchal et al. [in color]

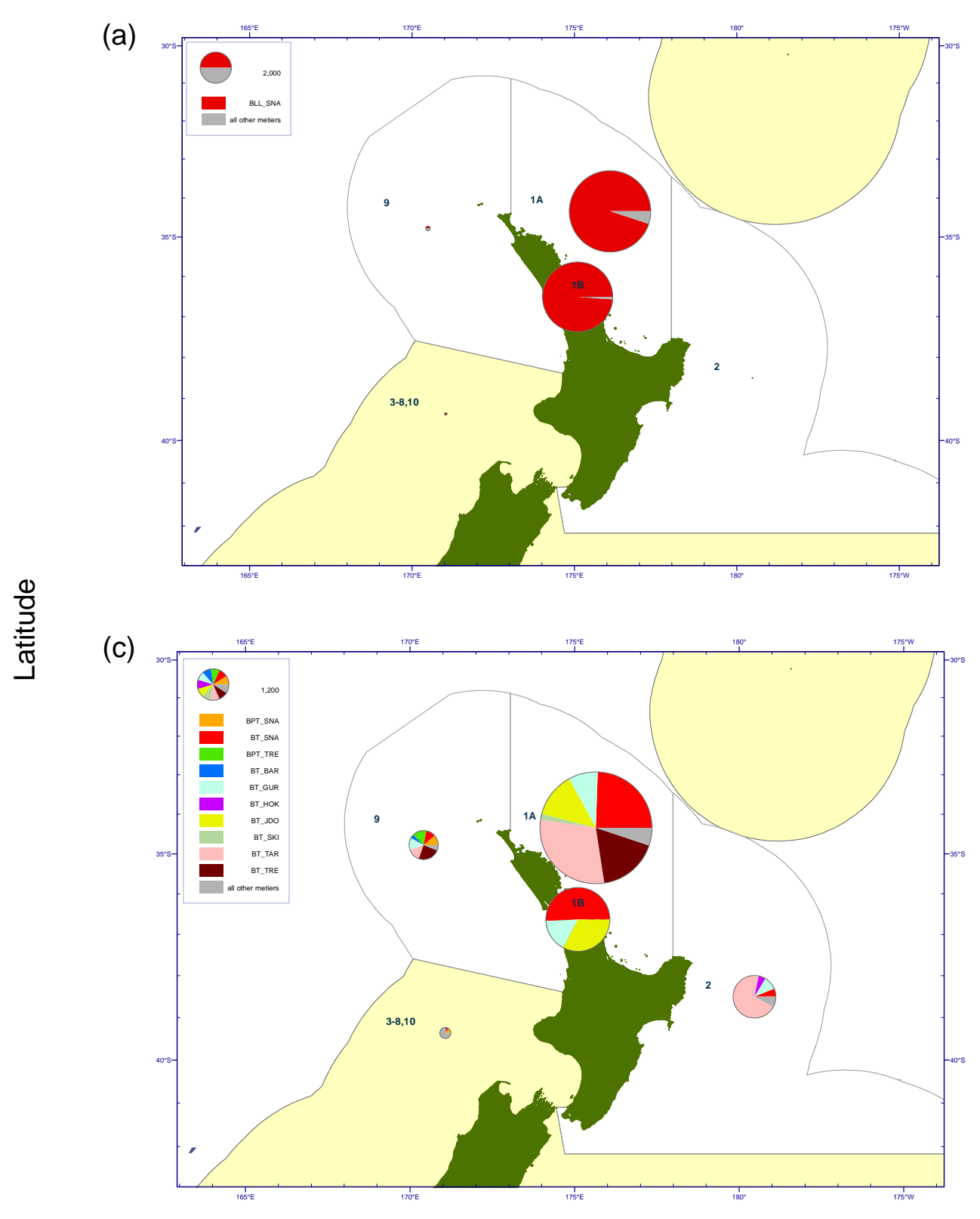

(b)

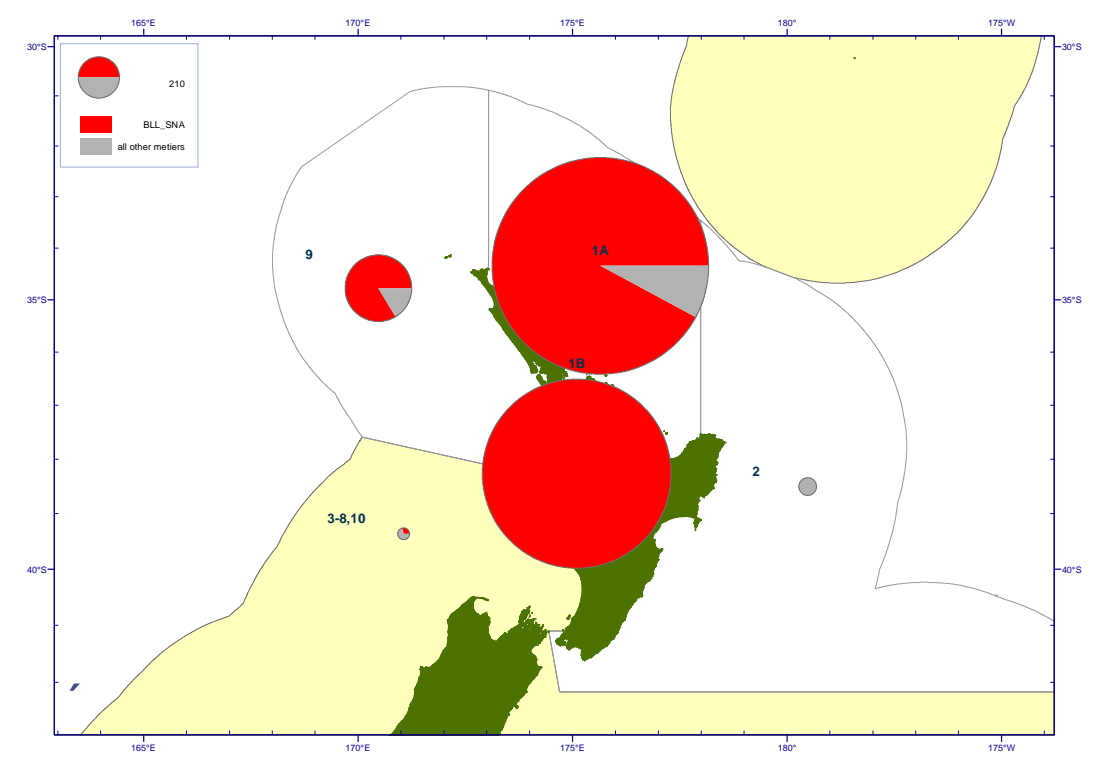

(d)

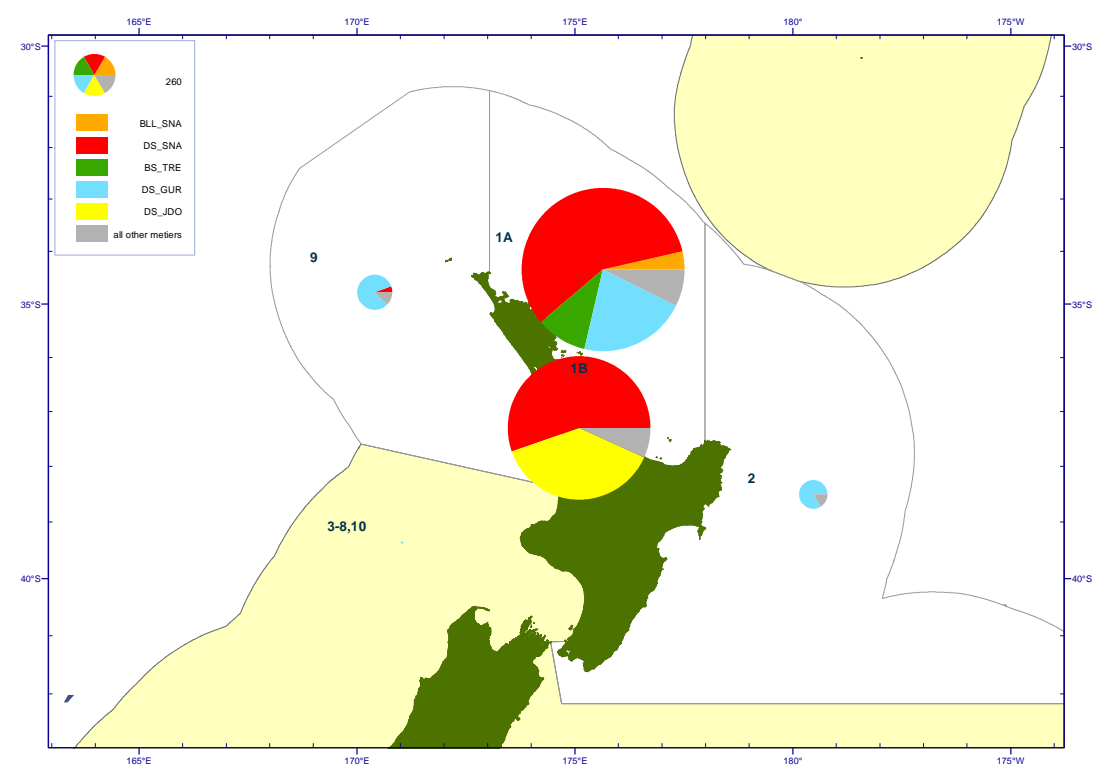


Figure 3. Spatial distribution of fishing effort by métier, using typology 1 , for the Northern snapper fleets, (a) 2 (small long-liners), (b) 3 (medium long-liners), (c) 4 (bottom trawlers) and, (d) 5 (Danish seiners). The codes are; BLL_SNA: bottom long-line snapper (Pagrus auratus), BPT_SNA: bottom pair trawl snapper, BT_SNA: bottom trawl snapper, BPT_TRE: bottom pair trawl trevally (Pseudocaranx dentex), BT_BAR: bottom trawl barracouta (Thyrsites atun), BT_GUR: bottom trawl gurnard (Chelidonichtys kumu), BT_HOK: bottom trawl hoki (Macruroñus novaezelandiae), BT_JDO: bottom trawl John dory (Zeus faber), BT_SKI: bottom trawl gemfish (Rexea solandri), BT_TAR: bottom trawl tarakihi (Nemadactylus macropterus), BT_TRE: bottom-trawl trevally (Pseudocaranx dentex), DS_SNA: Danish seine snapper, BS_TRE beach seine trevally, DS_GUR: Danish seine gurnard, DS_JDO: Danish John dory.

Figure 4. Marchal et al. [in color]

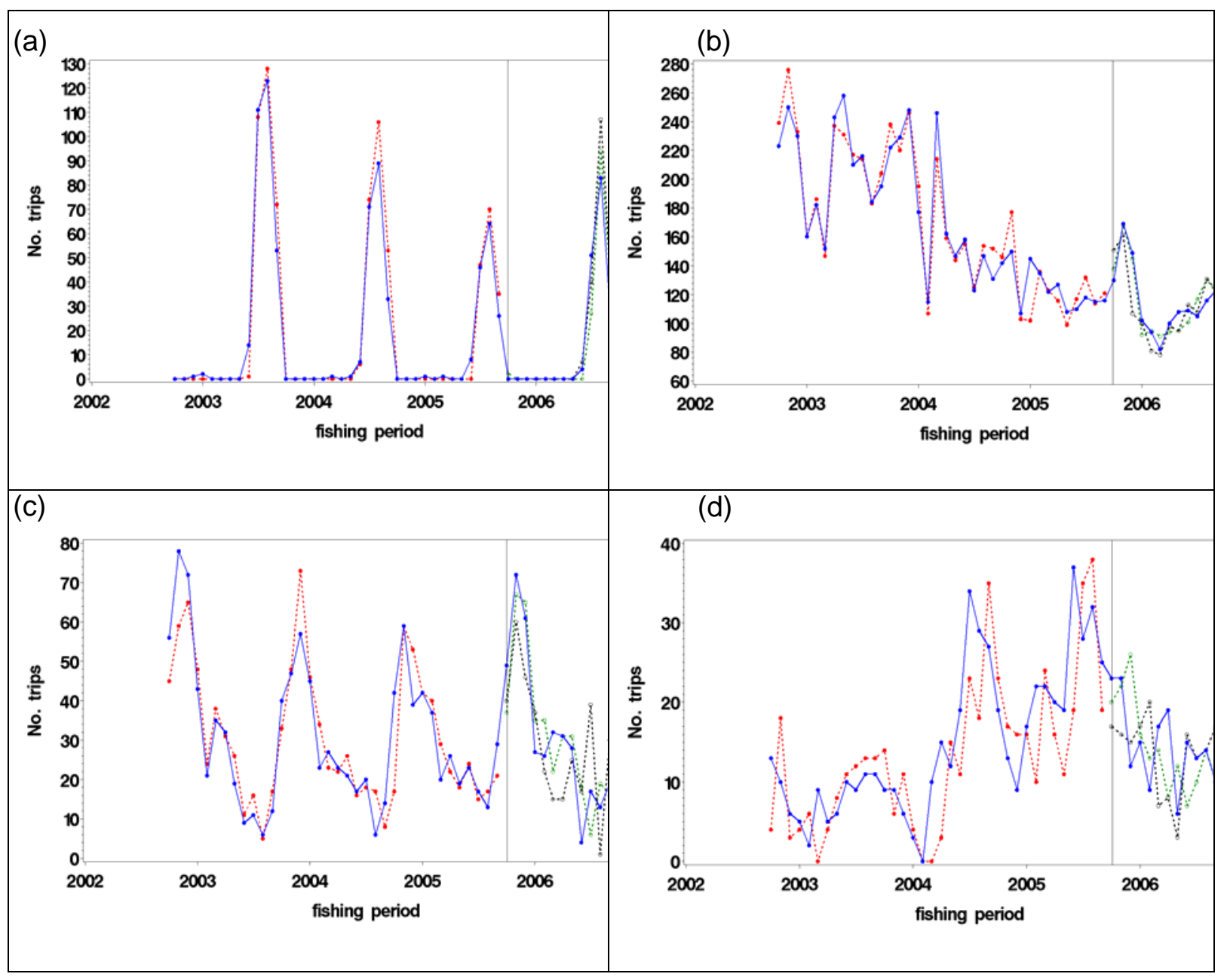

(e) 


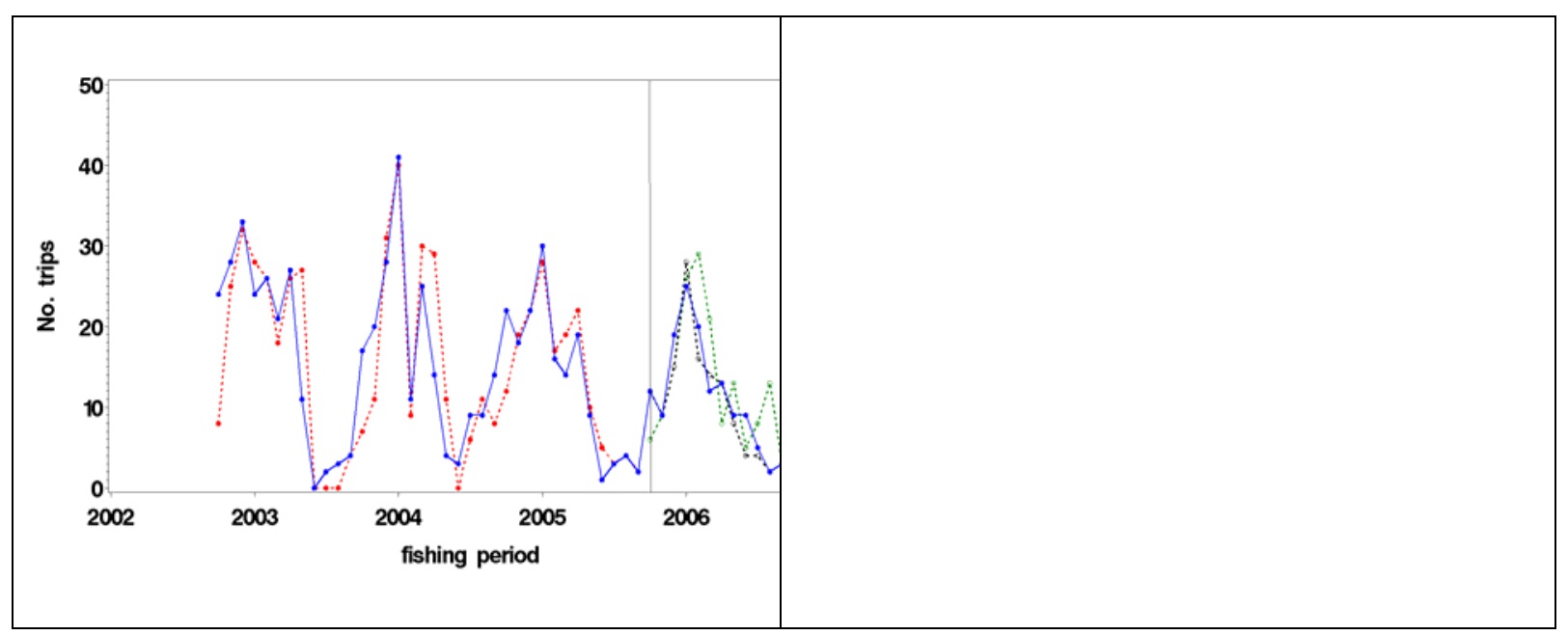

Figure 4. Number of trips observed (plain line, blue dots), calibrated over fishing years 20022005 (dotted line, red dots) and predicted over fishing year 2006 (one month ahead: dotted line, green circles; one year ahead: dotted line, black circles) number of trips per year and per month for each fleet operating its main métier (typology 1): (a) fleet 1 fishing with midwater trawls in management unit 7 and targeting hoki (Macruronus novaezelandiae), (b) fleet 2 fishing with bottom long-lines in management unit $1 \mathrm{~A}$ and targeting snapper (Pagrus auratus), (c) fleet 3 fishing with bottom long-lines in management unit $1 \mathrm{~B}$ and targeting snapper, (d) fleet 4 fishing with bottom-trawls in management unit $1 \mathrm{~A}$ and targeting snapper, (e) fleet 5 fishing with Danish seines in management unit 1B and targeting snapper. 
Figure 5. Marchal et al. [in color]

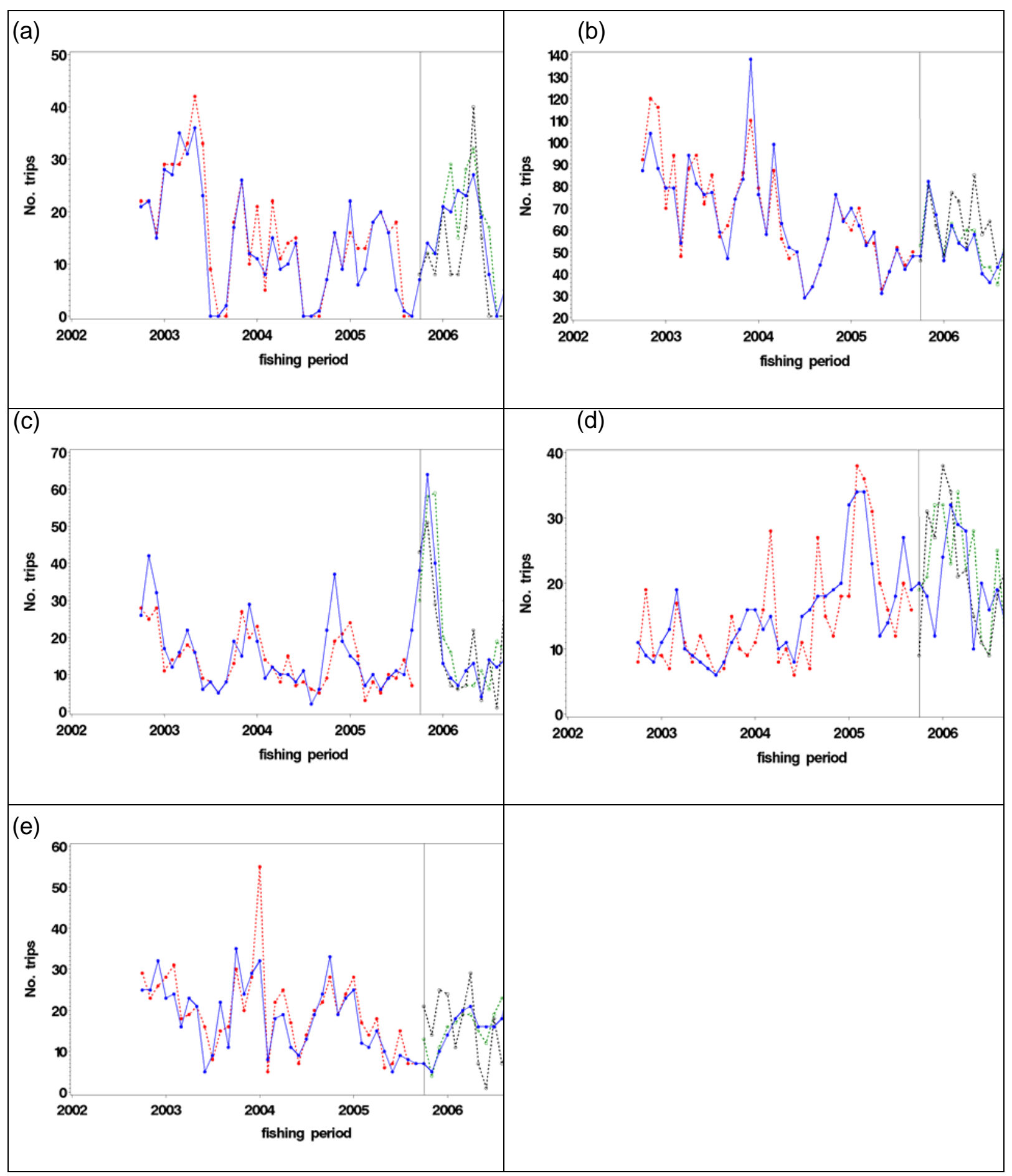

Figure 5. Number of trips observed (plain line, blue dots), calibrated over fishing years 20022005 (dotted line, red dots) and predicted over fishing year 2006 (one month ahead: dotted line, green circles; one year ahead: dotted line, black circles) number of trips per year and per month for each fleet operating its main métier (typology 2): (a) fleet 1 fishing with bottom trawls in management unit 3 and statistical area 022, (b) fleet 2 fishing with bottom long-lines in management unit $1 \mathrm{~A}$ and statistical area 002, (c) fleet 3 fishing with bottom long-lines in all statistical areas of management unit 1B, (d) fleet 4 fishing with bottom trawls in management unit $1 \mathrm{~A}$ and statistical area 003, (e) fleet 5 using Danish seines in management unit $1 \mathrm{~B}$ and statistical area 006. 